\title{
FEDERAL INCOME TAXATION OF OIL AND GAS OPERATIONS
}

\author{
M. A. CARTEN*
}

In his paper Mr. Carten discusses the Canadian federal income tax system and its application to the oil and gas industry. His principal concern is with those situations in which the taxation of the profits of the industry is not subject to the same basic principles of taxation as are other business operations in Canada.

\section{INTRODUCTION}

The purpose of this paper is to outline the principal features of the Canadian federal income tax system as it applies to the oil and gas industry. These rules have been the subject of major revisions in the past few years commencing with the amendments to the Income Tax Act (the amended Act) ${ }^{1}$ effective from January 1, 1972 with important amendments in the intervening period, the most significant of which were those introduced as a result of the Federal Budget of May 6, 1974.

With a few significant exceptions, the taxation of profits derived from oil and gas operations is subject to the same basic principles as are applicable to other business operations. Apparent variations in the treatment of transactions in oil and gas properties are essentially the result of the application of the legal principles peculiar to the creation and ownership of petroleum and natural rights and the different practices that have developed for the exploitation of such rights. ${ }^{2}$ The exceptions are the basic subject matter of this paper.

The subject is dealt with by first describing the recently enacted rules relating to the non-deductibility of expenses incurred in transactions with the Crown. The deduction of exploration and development costs, a topic which forms the focal point of much of the basic tax planning for oil and gas operations is divided into two main areas, namely, the categorization of such expenses for the purposes of determining the basis for their deduction and the special rules that are common to all categories as, for example, the rules relating to the deduction of partnership expenses. Transactions in oil and gas properties are accorded significantly different treatment under the amended Act and are, therefore, dealt with separately. Finally, the allowances that are based on production, being the deduction for earned depletion and the resource allowance, are briefly summarized.

No attempt is made to deal with the mining industry or that specialized area of the oil and gas industry that is treated as mining for income tax purposes, the development of bituminous sands, oil sands or oil shale. ${ }^{3}$ With the exception of the discussion of dispositions of oil and

* Barrister and Solicitor, Jones, Black \& Company, Calgary, Alberta.

1. Income Tax Act (I.T.A.), R.S.C. 1970, c. I-5 as amended by S.C. 1970-71-72, c. 1, 11, 30, 48, 63, 64; S.C. 1972, c. 9; S.C. $1973-74$, c. $14,29,30,44,45,49,51 ; 1974-75$, c. $26,50,58,71$. The Act as presently amended will be referred to as the amended Act. The Act as it read in its application to taxation years ending before 1972 shall be referred to as the former Act.

2. In large measure these practices are derived from the U.S. experience and it has generally been assumed that the U.S. experience in taxation will also be applicable. This is not always the case.

3. As defined under subsection 248(1) of the amended Act: “'minerals' do not include petroleum, natural gas or related hydrocarbons (except coal, bituminous sands, oil sands or oil shale)", and "'mineral resource' means: (a) base or precious metal deposit, (b) a coal deposit, (c) a bituminous sands deposit, oil sands deposit or oil shale deposit, (d) a mineral deposit in respect of which: (i) the Minister of Energy, Mines 
gas properties and some brief comment on farmouts there is no treatment of the various specialized rules relating to transactions in oil and gas properties. 4

\section{DEEMED INCOME}

The most radical difference in the taxation of oil and gas income is the rule introduced on May 6, 1974 that a taxpayer must include in income without any deduction in respect thereof, amounts payable to the Crown in right of Canada, the Crown in right of a Province, or one of Her agencies as royalties or other similar payments. The purpose and the effect of the changes in terms of the effective rate of taxation of oil and gas profits can best be understood by a review of the facts leading to their introduction..$^{5}$

To offset the effects of increasing world prices of oil resulting from the actions of the Organization of Petroleum Exporting Countries in 1973 Canada froze the domestic price of oil at $\$ 3.80$ per barrel being the price applicable immediately prior to the Arab oil embargo. ${ }^{6}$ At the same time an export tax on oil sold to the United States was imposed, the amount of which was essentially equivalent to the difference between the world price of oil and the domestic price. ${ }^{7}$

On April 1, 1974 the domestic price of oil at the wellhead was increased to $\$ 6.50$ per barrel, which price remained in effect until July 1 , 1975. On July 1,1975 the wellhead price was increased to $\$ 8.00$ per barrel and was again increased to $\$ 9.50$ per barrel effective June 1,1976 . On January 1, 1975 the border price for Canadian natural gas exports was increased to $\$ 1.00$ per MCF and was further increased in August, 1975 to $\$ 1.40$ per MCF and in November of 1975 to $\$ 1.60$ per MCF. During this same period domestic prices for natural gas exported from Alberta for domestic markets increased to $\$ .94$ per MCF at the Alberta border.

\section{Provincial Initiatives}

During the period when the prices for oil and gas were being increased the governments of the producing provinces changed their royalty structures with the result that the bulk of the revenue resulting from the price increases of oil and natural gas was appropriated to the provinces.

The Province of Alberta introduced a new schedule of royalties effective generally from April 1, 1974 which varied according to the rate of production, a price determination by the Government of Alberta and the classification of the oil as "old oil" or "new oil". Basically, "new oil"

and Resources has certified that the principal mineral extracted is an industrial mineral contained in a non-bedded deposit, (ii) the principal mineral extracted is sylvite, halite or gypsum, or (iii) the principal mineral extracted is eilica that is extracted from sandstone or quartzite".

4. For an excellent discussion of this subject see Verchere, B. and Donaghey, D., Structuring Mineral Resource Property Ventures, (1976) 23 Can. Tax J., 1.

5. An historical analysis of this subject can also be found in Brown, The Fight Over Resource Profits (1974) 22 Can. Tax J. 315.

6. See An Energy Strategy for Canada and Policies for Self-reliance, issues under the authority of the Minister of Energy, Mines and Resources (1976), p. 17. Information on prices is obtained from this source or from the National Energy Board.

7. While Canada was at the time self-sufficient in oil production and indeed a net exporter the eastern provinces were required to buy international oil at world prices. The export tax was seen as a method of subsidizing these costs and reducing the economic impact of the OPEC action. The policy of the Government of Canada, although not clearly articulated at the time, was that there be a single price for oil with variations only for transportation and quality difference. 
was oil obtained from certain exploratory wells licenced on or after April 1,1974 and additional oil obtained as a result of enhanced recovery schemes approved on or after April 1, 1974. The formulae, which are complex, resulted in a significant increase in the royalties payable to the Province of Alberta and presently range, for example, from $26.275 \%$ based on a monthly production of 1,200 barrels of oil to $36.758 \%$ based on a monthly production of 3,000 barrels of new oil. ${ }^{8}$

As well, effective from January 1, 1974 Alberta established new natural gas royalty rates which also distinguish between "new gas" and "old gas" and vary according to the price being received. The royalties provide for a sliding scale royalty on "old gas" ranging from $22 \%$ at a price of 264 per MCF to $42.68 \%$ at a price of $\$ 1.20$ per MCF. The royalty rates on "new gas" range from $22 \%$ at a price of 264 per MCF to $31.616 \%$ at a price of $\$ 1.20$ per MCF. Similarly, "new gas" is distinguished from "old gas" as being gas discovered after January 1, 1974 or obtained from a pool not produced prior to January $1,1974 .{ }^{\circ}$

Late in 1973 the Province of Saskatchewan also amended its oil and gas legislation with the passage of The Oil and Gas Conservation Stabilization and Development Act (1973). ${ }^{10}$ The general effect of the statute and regulations passed thereunder is that a producer in the province of Saskatchewan currently pays a mineral tax or a royalty surcharge on his share of crude oil production equivalent to $100 \%$ of the increase in the per barrel price received over the wellhead prices set by the Government of Saskatchewan. After payment of such income tax or royalty surcharge the amount received by producers presently ranges from approximately $\$ 3.96$ per barrel to $\$ 4.65$ per barrel, depending upon the quality of the crude and the area from which it is obtained. In addition, producers pay lessor royalties which, on oil, are sliding scale royalties which vary according to the level of production and range from up to $10 \%$ on wells producing up to 600 barrels per month, from $10 \%$ to $22 \%$ on wells producing from 600 barrels to 2,040 barrels per month, and exceed $22 \%$ in the case of wells producing in excess of 2,040 barrels per month. At present the royalty on natural gas is 24 per MCF.

In 1973 the Province of British Columbia created by statute the British Columbia Petroleum Corporation to acquire from Westcoast Transmission, all of its contracts for the purchase of natural gas from producers in the province and thereafter to purchase under contract all of the natural gas produced in the province."11 Under contracts entered into with the producers the Corporation has agreed to pay 354 per MCF for "old gas" and 554 MCF for "new gas". The Corporation is, however, entitled to hold back from the price paid for "old gas" the sum of 154 per MCF as a work credit which may be earned by the vendor of the gas in the performance of further exploration in the province or which may be assigned to third parties and earned by them in a similar manner. ${ }^{12}$

8. Alta. Reg. $93 / 74$ (1974).

9. Alta. Reg. 16/74: 19/74 (1974).

10. S. Sask. 1973-74, c. 72. See generally Crawford, New Tax Measures Affecting the Petroleum Industry in Saskatchewan in 1974, 1974 Conference Report Canadian Tax Foundation at 374. It is understood that the province will shortly amend and simplify its royalty structure.

11. S. B.C. 1973 , c. 140 .

12. Under typical agreements entered into between British Columbia Petroleum Corporation and a producer of gas, the payment for the gas is as follows: "The price for gas delivered pursuant hereto on or after the lst day of November 1975 , ghall be (a) $55 \%$ for each mcf of residue gas derived from New Gas delivered hereunder, and (b) $35 €$ for each mef of residue gas derived from Old Gas delivered hereunder, provided that for each mef of residue gas derived from Old Gas so delivered on or after the 1st day of November, 1975, the 


\section{Federal Response}

As provincial royalties were a deductible expense in calculating the income of a taxpayer for federal income tax purposes, the effect of the amendments was a decline in the proportion of the total tax and royalty burden going to the federal government. The federal government's response was simple but direct. It would disallow the deduction of Crown royalties and other similar payments made by a taxpayer. The necessary amendments were introduced on May 6, 1974 but the government was subsequently defeated on the Bill and a general election was called. After its re-election the proposals were re-introduced on November 18, 1974. In his speech to the House of Commons on November 18, 1974 the Minister of Finance referred to the proposals introduced on May 6, 1974 and said:

Fourth, I proposed that royalties, taxes and other like payments to governments should no longer be recognized as a deduction in computing income for tax purposes. My reasons for this action were described in the May 6 budget and I have elaborated upon them since. I am satisfied that this is a necessary step in order to avoid the erosion of the federal tax base.

I have considered carefully permitting deductibility of royalties and I have concluded that this approach does not offer a practical solution.

I acknowledge that royalties in respect of property rights have traditionally been deductible as a business expense. However, in tax reform, we began the process of disallowing certain income royalties in the mineral field and substituting federal tax abatements. Today, it is evident that a royalty is no longer a royalty in the traditional meaning of the word. There have emerged various provincial charges which are thinly disguised income taxes.

Today provincial charges take many forms. They are no longer limited to flat charges against a unit of production. Now there are provincial charges that are determined by price, profit and volume. In addition, there are provincial claims exercised through joint ventures and marketing boards. In fact, there are so many kinds of provincial charges and claims that it would be virtually impossible to draft workable legislation which could distinguish between bona fide royalties, traditionally deductible, and other taxes and charges.

That being 8o, we have chosen to disallow the deduction of all these levies and to make room for the provinces by giving additional tax abatement.

In this way, the provincial taxes and charges and the federal taxes will each be discrete, and visible decisions, which each can take in the light of what they know the other is doing, giving full recognition to the needs of the industries.

Surely the goal is to find a compromise which gives reasonable results in financial terms to the provinces, to the industries and to the federal government. This is what my proposals aim to do. ${ }^{13}$

The abatement allowed the province was a reduction in the effective federal tax rate on resource based profits to $30 \%$ in 1974, to $28 \%$ in 1975 and to $25 \%$ in 1976 and thereafter. The abatement subsequently proved unworkable and was replaced by a resource allowance of $25 \%$ of net revenues derived from oil and gas and mining operations. ${ }^{14}$

buyer shall: (i) hold back out of the purchase price otherwise payable the sum of 154, (ii) record a credit (herein called a "Credit") in favour of the seller, which Credit shall be subject to the terms of Schedule C to this Agreement, (iii) confirm to the seller that such Credit has been so recorded (such confirmation constituting full satisfaction by the buyer of the portion of the purchase price held back as aforesaid); it being agreed that New Gas is raw gas which comes within one of the categories (that is, one of the classes of gas described in the price policy letter dated November 21, 1974) which as of the lst day of January, 1975 , took a price on sale to the buyer of not less than $23 \%$ per mcf of residue gas derived therefrom, and Oid Gas is raw gas which does not qualify as New Gas."

13. House of Commons Debates, 1st Sess. 30th Parl. at 1424.

14. S.C. 1974-75, c. 71; I.T.A. paragraph 20(1)(v). 


\section{Legislation}

\section{(a) Crown Royalties and Other Payments}

Under paragraph $18(1)(\mathrm{m})^{15}$ of the Act, it is specifically provided that in computing the income of a taxpayer, no deduction may be claimed for any amount paid or payable in the year, or the fair market value of property paid or payable in the year, to the Crown, an agent of the Crown or a corporation, commission or association controlled by the Crown (a Crown Agency), as a royalty or an equivalent amount, tax, rental, bonus, levy or other amount if it is reasonable to regard it as being in relation to the acquisition, development or ownership of a Canadian resource property or the production in Canada of petroleum, natural gas or related hydrocarbons from an oil or gas well or mineral resource that is situated on property in Canada from which the taxpayer had at the time of production a right to take or remove petroleum, natural gas or related hydrocarbons.

With the exception of amounts paid to a Crown agency in respect of Indian lands, or as municipal or school taxes, all such payments are covered whether payable by operation of law or under the terms of a contract. However, a specific deduction is provided for payments to a Crown agency where the payment is the first amount payable in respect of the right, licence or privilege to explore for, to explore for and take, or to take petroleum or natural gas (other than a mineral resource) from a place in Canada. The item is treated as a Canadian development expense and is deductible essentially on a $30 \%$ declining basis.

To cover the situation where reserved royalties and similar payments are considered not to form part of the taxpayer's income for tax purposes, paragraph 12(1)(o) provides in language that is virtually identical to paragraph $18(1)(\mathrm{m})$ that such amounts will be included in the taxpayer's income as income from a business or property..$^{16}$

The legislation, as described, is generally effective from May 6, 1974 except that, for the period from May 6, 1974 to November 18, 1974, amounts that are bonuses or that cannot be regarded as being attributable to the production of petroleum or natural gas in Canada as, for example, taxes payable in respect of non-producing reserves, are not covered and are deductible in calculating the taxpayer's income. ${ }^{17}$

Both of paragraphs $12(1)(0)$ and $18(1)(\mathrm{m})$ provide that the amounts

15. Paragraph $18(1)(\mathrm{m})$ of the Act provides that: "In computing the income of a taxpayer from a businesa or property no deduction shall be made in respect of . . . (m) any amount paid or payable in the year or the fair market value of any property paid or payable in the year (other than an amount or property paid or payable to Her Majesty in right of Canada for the use and benefit of a band or bands as defined in the Indian Act) to (i) Her Majesty in right of Canada or a province, (ii) an agent of Her Majesty in right of Canada or a province, or (iii) a corporation, commission or association that is controlled, directly or indirectly in any manner whatever, by Her Majesty in right of Canada or a province or by an agent of Her Majesty in right of Canada or a province as a royalty or an equivalent amount, tax (other than a tax or portion thereof that may reasonably be considered to be a municipal or school tax levied for the purpose of providing services in the immediate area of the property of the taxpayer), rental, bonus, levy or otherwise or as an amount, however described, that may reasonably be regarded as being in lieu of a royalty or an equivalent amount, tax, rental, bonus, levy or other amount (whether such royalty or equivalent amount, tax, rental, bonus, levy or other amount is paid or payable pursuant to any other Act or a contract) that may reasonably be regarded as being in relation to: (iv) the acquisition, development or ownership of a Canadian resource property, or a property that would have been a Canadian resource property if it had been acquired after 1971, or (v) the production in Canada of (A) petroleum, natural gas or related hydrocarbons, or (B) metal or industrial minerals to any stage that is not beyond the prime metal stage or its equivalent from an oil or gas well or mineral resource situated on property in Canada from which the taxpayer had, at the time of such production, a right to take or remove petroleum, natural gas or related hydrocarbons or a right to take or remove metal or industrial minerals."

16. I.T.A. paragraph $12(1)(0)$ is identical to paragraph $18(1)(\mathrm{m})$ except that instead of referring to amounts payable to a Crown agency it refers to amounts receivable by a Crown agency.

17. S.C. $1974-75$, c. 26 subsections 4(5), 7(5). 
payable in respect of oil and gas production will only be included in income where the production is from a property in respect of which the taxpayer had at the time of such production a right to take or remove petroleum or natural gas or related hydrocarbons. These rights are generally considered to belong only to the lessor or working interest owner as that party is the only person entitled to take or remove petroleum or natural gas from the specific property. The legislation would not, for example, require the original Crown lessee to include any amount in income where the original lease has been subleased to another person or farmed out with only a reserved royalty being retained by the Crown lessee. Similarly, parties having a share in production under contractual arrangements which do not grant the right to take or remove petroleum from the property such as, for example, gross overriding royalty interests or net profits interests, will not be required to include any portion of the Crown royalties in income.

Where the taxpayer is reimbursed under a contract for mineral taxes or other similar charges, the payment of which would otherwise be disallowed as a deduction in calculating his income pursuant to paragraph 18(1)(m), section 80.2 will deem such payments to have been made directly to the Crown by the reimbursing party. As a result the deduction of such payments will effectively be disallowed to the reimbursing party even though actually paid by him to the reimbursed party.

Section 80.2 states:

Where pursuant to a contract between a taxpayer and another person (in this section referred to as the "payee") any amount is paid or payable by the taxpayer or any property is transferred by the taxpayer to the payee as reimbursement in respect of any amount paid or payable referred to in paragraph $18(1)(\mathrm{m})$ or the fair market value of any property paid or payable referred to in that paragraph by the payee to any of the persons referred to in any of subparagraphs $18(1)(\mathrm{m})(\mathrm{i})$ to (iii), for the purposes of this Act the following rules apply:

(a) the taxpayer shall be deemed to have paid the amount or property, as the case may be, to a person or persons referred to in any of those subparagraphs,

(b) the payee shall, to the extent of that reimbursement, be deemed not to have paid an amount or property, as the case may be,

(c) the payee shall be deemed not to have received any reimbursement from the taxpayer, and

(d) paragraph 12(1)(0) shall not apply in respect of the amount or property paid or payable, as the case may be.

Although the legislative intention of this section appears to be to shift the additional tax burden arising as a result of the operation of paragraphs $12(1)(0)$ and $18(1)(\mathrm{m})$ to the party effectively bearing the financial obligation, it is not entirely clear whether that intention has been achieved. Where the amount paid by the reimbursing party is regarded as being in relation to the ownership or development of a Canadian resource property, section 80.2 appears to operate as intended such that the reimbursing party will not be entitled to any deduction in respect of payments made on behalf of the reimbursed party. However, if the payment is regarded as being in relation to the production of oil or gas, section 80.2 will be effective to disallow the deduction of such payments by the reimbursing party only if that party has the right to take or remove petroleum or natural gas from the property in respect of which the payment is being made. Should the reimbursed party not have such a right it would appear that neither the reimbursed party nor the 
reimbursing party is technically liable to include any amount in income in respect of such payments made to the Crown.

Clause 30 of Bill C-97 would amend section 80.2 to read as follows:

Where

(a) a taxpayer, under the terms of a contract, reimburses another person for an amount or the fair market value of property paid or payable by that person and such amount or value of property as the case may be is included in the income of that other person or denied as a deduction in computing income of that other person by virtue of paragraph $12(1)(0)$ or paragraph $18(1)(\mathrm{m})$ as the case may be

(b) the taxpayer was resident in Canada or carrying on business in Canada at the time of the reimbursement

the following rules apply for the purposes of this Act

(c) the taxpayer shall be deemed not to have made the reimbursement to the other person but to have paid an amount described in paragraph $18(1)(\mathrm{m})$ equal to the amount of the reimbursement, and

(d) the other person shall be deemed not to have received the reimbursement from the taxpayer.

As amended, section 80.2 would be more comprehensive in scope such that where a taxpayer reimburses a party who would otherwise be liable to include in income amounts referred to in paragraph $12(1)(0)$ or would be disallowed a deduction in respect of amounts referred to in paragraph $18(1)(\mathrm{m})$, the reimbursing party will be effectively substituted for the person who would otherwise be responsible for such Crown payments. Section 80.2 will only apply where the reimbursing party is a resident of Canada or otherwise carries on business in Canada. This rule is apparently designed to foreclose a practice which has developed whereby non-residents are, as part payment for minerals purchased by them, reimbursing the resident producer for provincial property taxes. Under such an arrangement the Canadian resident is effectively not taxable on such amounts by virtue of section 80.2 and the non-resident is also not taxable as he was not carrying on business in Canada.

Notwithstanding its restrictions section 80.2 as amended will be a useful device for effectively consolidating income of related corporations and matching taxable income with otherwise unuseable exploration expenses or operating losses.

A topic of continuing concern in the oil and gas industry is the possible application of paragraphs $12(1)(0)$ and $18(1)(\mathrm{m})$ to commercial arrangements with corporations that are controlled by the Crown. Under the legislation as currently drafted it seems clear that royalties and other similar payments made to such corporations will either be included in income of the payor under paragraph $12(1)(0)$ or disallowed as a deduction to the payor under paragraph $18(1)(\mathrm{m})$. This is the case whether the arrangements were entered into with the corporation at a time when it was controlled by the Crown or at a time prior to the acquisition of control by the Crown. ${ }^{18}$

The current practice of the Department of National Revenue is not to apply paragraphs $12(1)(0)$ and $18(1)(\mathrm{m})$ to transactions of a commercial nature with such corporations. To provide legislative sanction to the practice, Bill C-97 would amend paragraphs 12(1)(o) and 18(1)(m).

The payments that currently must be included in income under

18. For example, a taxpayer paying royalties to Atlantic Richfield Canada Ltd. (Arcan) would, after the acquisition of that company by Petro-Canada, not be entitled to deduct the royalties as Arcan would thereafter be a corporation controlled by Her Majesty in right of Canada. 
paragraph $12(1)(0)$ or disallowed as a deduction under paragraph $18(1)(\mathrm{m})$ are payments that are being made:

as a royalty or an equivalent amount, tax (other than a tax or portion thereof that may reasonably be considered to be a municipal or school tax levied for the purpose of providing services in the immediate area of the property of the taxpayer), rental, bonus, levy or otherwise or as an amount, however described, that may reasonably be regarded as being in lieu of a royalty or an equivalent amount, tax, rental, bonus, levy or other amount (whether such royalty or equivalent amount, tax, rental, bonus, levy or other amount is receivable pursuant to any other Act or contract).

Under the proposed amendments the payments that would be included in income under paragraph 12(1)(o) or disallowed as a deduction under paragraph $18(1)(\mathrm{m})$ are payments that are a:

royalty, tax (other than a tax or portion thereof that may reasonably be considered to be a municipal or school tax) lease rental or bonus or as an amount, however described, that may reasonably be regarded as being in lieu of any such amount.

It is worth noting that there has been deleted from the original language the following expressions: "or an equivalent amount", "levy or otherwise", and "(whether such royalty or equivalent amount, tax, rental, bonus, levy or other amount is receivable pursuant to any other Act or a contract)". In addition, whereas previously the language referred to a "rental, bonus, levy, or otherwise", the language now refers to a "lease rental or bonus" without the insertion of a comma between the words rental and bonus.

It would appear that there is a legislative intention to remove from the operation of paragraphs $12(1)(0)$ and $18(1)(\mathrm{m})$ transactions which have a commercial flavour. This, it is submitted, is evident from the removal from the language "or an equivalent amount" and particularly by the removal of the language in parentheses relating to payments receivable under a contract. It may reasonably be anticipated that the Department of National Revenue will construe this section as not applying to commercial transactions entered into with corporations controlled by Her Majesty. Whether or not it will construe the paragraphs as applying to commercial transactions entered into directly with Her Majesty is another matter.

\section{(b) Sales to Crown Agencies}

As adverted to, British Columbia took a different approach in the collection of what it deemed to be its fair share of revenues derived from the production of natural gas in the province. By purchasing gas at substantially less than the market price and selling that gas in the United States at the market price British Columbia accomplished its objective without the use of Crown royalties. As paragraphs 12(1)(o) and $18(1)(\mathrm{m})$ were clearly inapplicable to this situation subsections $69(6)$ and (7) were enacted.

Under subsection 69(6) of the amended Act where a taxpayer who operates an oil or gas well disposes of oil or gas produced from such wells to a Crown agency pursuant to a law or contract requiring the disposal of the oil or gas for no proceeds, or for proceeds less than the fair market value thereof, he shall be deemed to have received proceeds equal to the deemed fair market value thereof determined under the Act without regard to such law or contract. ${ }^{19}$ Under these circumstances the fair market value will be determined by reference to the average 
proceeds of disposition that became receivable by the Crown agency on the disposition of similar quality oil or gas during the month in which the taxpayer disposed of its oil or gas to the Crown agency less the average aggregate of the expenses incurred by the Crown agency during that month (including depreciation) that are reasonably attributable to transmitting, transporting, marketing or processing the production. ${ }^{20}$

Similarly, where a taxpayer acquires from a Crown agency oil or gas produced in the operation of an oil or gas well in Canada at a cost that is in excess of the fair market value thereof at the time he so acquired the petroleum, the taxpayer shall be deemed to have acquired the oil or gas at the fair market value thereof without regard to any law or contract requiring that he acquire the oil or gas at the higher price. ${ }^{21}$ For these purposes the fair market value of the oil or gas shall be deemed to be an amount equal to the amount initially paid to the taxpayer by the Crown agency in respect of that oil or gas.22

Under the amended Act the taxpayer will be required to include in income an amount substantially in excess of the sale price under contracts entered into by it with the British Columbia Petroleum Corporation. Under the legislation it is, of course, impossible for a taxpayer to precisely determine the amount which he must include in income as he cannot determine the average aggregate of the expenses incurred by the Crown agency in transmitting, transporting, marketing or processing the gas. The British Columbia Petroleum Corporation has provided producers with a schedule of amounts which it believes to be the amount that must be included in income pursuant to section 69(6) of the Income Tax Act. The fair market value figures provided by the Corporation to date have ranged from $\$ .36$ per MCF in May, 1974 to $\$ .80$ per MCF in September, 1974 and $\$ 1.03$ per MCF for May, 1976. While the Department of National Revenue is not bound by such figures it is understood that they are being accepted as accurate.

\section{DEDUCTION OF EXPLORATION AND DEVELOPMENT COSTS}

Expenses incurred in drilling and exploration for oil and gas have been regarded at common law as being expenditures on account of capital and therefore not deductible in computing a taxpayer's income, except to the extent expressly permitted by statute. ${ }^{23}$ For some time, however, the Income Tax Act has permitted such expenses to be deducted in computing income. ${ }^{24}$ The expenses that were deductible and the income against which they could be applied have, however, varied over the years. As a result, it is necessary to divide the expenditures into different categories, generally on a chronological basis, to determine the amount of the deductions and the order in which they must be claimed.

Furthermore, only those persons or associations engaged principally in the oil and gas business were entitled to deduct such expenses on a current basis. Consequently, the deductibility of expenses has also varied according to the characterization of the taxpayer as a "principal

20. I.T.A. subsection $69(8)$.

21. I.T.A. subsection $69(7)$.

22. I.T.A. subsection 69(9).

23. Siscoe Gold Mines Limited v. M.N.R. [1945] C.T.C. 397; 2 D.T.C. 749 (Exch. Ct.); Anglo Canadian Oil Company Limited v. M.N.R. [1947] C.T.C. 47 ; 3 D.T.C. 950 (Exch. Ct.).

24. For an historical analysis of the early legislation see McDonald. Preferential Taxation of Natural Resource Industries in Canada, 30 Can. Bar Rev. 119 and The Tax Treatment of Oil and Gas Transactions 31 Can. Bar. Rev. 158. 
business corporation" or otherwise. ${ }^{25}$ While there is currently no logical reason for permitting the deduction of exploration and development expenses incurred by such "principal business corporations" on a different basis than that allowed other taxpayers, the distinction remains at least with respect to expenditures incurred prior to May 25, 1976.

As a result in determining the deductibility of expenses regard must be had to the status of the taxpayer under the Act, the character of the expenses themselves and the time when they were incurred.26 The proposed amendments under Bill C-97 have to some extent eliminated the privileges previously afforded principal business corporations as exploration expenses incurred after May 25, 1976 are deductible on essentially the same basis by all taxpayers.

\section{Principal Business Corporations}

The definition of a "principal business corporation" varies according to the year in which the expenses that are sought to be deducted were incurred. For expenses incurred from 1949 to April 10, 1962 it is a corporation whose principal business is production, refining or marketing of petroleum, petroleum products or natural gas or exploring or drilling for petroleum or natural gas or mining or exploring for minerals.27

For expenses incurred after April 10, 1962 and before 1972, the definition is expanded to include (i) processing mineral ores for the purpose of recovering metals therefrom; (ii) a combination of processing mineral ores for the purpose of recovering metals therefrom and processing metals recovered from the ores so processed; (iii) fabricating metals; and (iv) operating a pipeline for the transmission of oil or natural gas. ${ }^{28}$

With respect to expenses incurred after 1972, the definition is again expanded to include a taxpayer whose business is the production or marketing of sodium chloride or potash, or whose business includes manufacturing products the manufacturing of which involves processing sodium chloride or potash.29 Thus, to determine whether a specific

25. The right accorded principal business corporations to deduct exploration costs has been characterized by the Supreme Court as incentive legislation. Mr. Justice Dickson speaking for the majority in Gustauson Drilling (1964) Limited v. M.N.R. [1976] C.T.C. 1, at 3, 755451 (S.C.C.), at 5451 said: "Parliament since 1949 has encouraged the exploration for petroleum and natural gas by permitting corporations 'whose principal business is production, refining or marketing or petroleum, petroleum products or natural gas or exploring or drilling for petroleum or natural gas' (hereafter referred to as 'oil companies') to deduct their drilling and exploration expenses in computing income for the purpose of the Income Tax Act."

26. The deduction of such expenses rests on the Act as presently amended and on the Income Tax Application Rules 1971. While expenses may have been incurred prior to the year in which the deduction is claimed, the right to the deduction depends on the applicable legislation at the time the deduction is in fact claimed and not at the time when incurred. In this regard, Dickson J. said in Gustauson Drilling (1964) Ltd. v. M.N.R. supra, n. 2 at 9. and 6456: "One may fall into error by looking upon drilling and exploration expenses as if they were a bank account from which one can make withdrawals indefinitely or at least until the bank account is exhausted. No one has a vested right to continuance of the law as it stood in the past; in tax law it is imperative that legislation conform to changing social needs and governmental policy. A taxpayer may plan his financial affairs in reliance on the tax laws remaining the same; he takes the risk that the legislation may be changed."

And further at 7 and 5455: "The Income Tax Act contains a series of very complicated rules which change frequently for the annual competition of world income. The statute in force in the particular taxation year must be applied to determine the taxpayer's taxable income for the year."

27. ITAR 29(1) and 29(3).

28. ITAR 29(4).

29. I.T.A. subparagraph $66(15)(h)(v i i)$ provides that a principal business corporation means also a corporation whose principal business is: "production or marketing of sodium chloride or potash, or whose business includes manufacturing products the manufacturing of which involves processing sodium chloride or potash".

It is not clear whether the principal business corporation whose business includes manufacturing products 
expense is deductible one must determine whether the taxpayer is a principal business corporation as that expression is defined in relation to the period when the expenses were incurred. For example, a corporation whose principal business is operating a pipeline may deduct expenses incurred after April 10, 1962 but may not deduct expenses incurred prior to that date.

The expression "principal business" is not defined under the amended Act and whether the enumerated activities constitute the principal business of a taxpayer is a question of fact to be determined by an examination and comparison of all the circumstances concerning each of the various types of businesses in which the company is engaged.30

In Dillman Oil Properties Ltd. v . M.N.R. ${ }^{31}$ the Tax Appeal Board enumerated four principal tests that it considered relevant in determining whether the principal business of a corporation was exploring or drilling for oil. They are:

1. The Income Test: What portion of the corporation's income is attributable to operating or drilling for oil?

2. The Expense Test: What portion of the corporation's expense can be attributed to the "oil phase" of its operations?

3. The Capital Test: How much of the corporation's capital is employed in the various stages of its exploration business?

4. The Activity Test: In what capacity were most of the corporation's employees engaged?

In that case the Board held that the corporation was principally engaged in providing services as a drilling contractor and therefore the principal business was not exploring or drilling for oil as that expression was used in the legislation. Although contract drillers have by long standing practice been treated as principal business corporations by the Department of National Revenue, it nevertheless continues to apply the tests set forth in Dillman. ${ }^{32}$ In M.N.R. v. Consolidated Mogul Mines Limited" the meaning of "principal business" was broadened to include not only activities conducted on properties in which the corporation had a direct interest but also to activities carried on by the corporation in respect of properties owned by a subsidiary. Thus, where a parent corporation conducts exploration activities in connection with property owned by affiliated corporations or subsidiaries, it will nevertheless be treated as a principal business corporation notwithstanding that it does

the manufacturing of which involves processing sodium chloride or potash must otherwise qualify under paragraph $66(15)(\mathrm{h})$, whether its principal business must involve those activities or whether any corporation whose business includes those activities will qualify.

30. American Metal Company of Canada, Ltd. v. M.N.R. [1952] C.T.C. 302 at 306; 52 D.T.C. 1180 at 1182 (Exch. Ct.).

31. 40 Tax A.B.C. 17, 66 D.T.C. 2 (T.A.B.).

32. In paragraph 2 of Interpretation Bulletin IT 290, the D.N.R. states its position as to the meaning of the words "principal business" as it is used in relation to Non-Resident-Owned Investment Corporations. It states: "The word 'principal' is not defined in the Act but it is considered that the words 'chief and 'main' are synonymous to it. The question of when income from the sources mentioned in subparagraph $133(8)$ (d)(iv) becomes a principal business is one of fact to be determined by an examination and comparison of all the facts concerning each of the various types of business in which the corporation is engaged throughout the period from the later of June 18,1971 or the date of incorporation and ending on the last day of the taxation year in respect of which the expression is being applied. Although none of the following criteria may be sufficient in or by themselves, they should be considered in determining which of the corporation's businesses is its principal business for the purposes of subparagraph 133(8)(d)(iv) of the Act: (a) the profits realized by each one of a corporation's businesses; (b) the volume and the value of the gross sales or transactions of each business; (c) the value of the assets of each business; (d) the capital employed in each business; and (e) the time, attention and efforts expended by the employees, agents or officers of the corporation in each business.

33. [1968] C.T.C. 429; 68 D.T.C. 5284 (S.C.C.). 
not directly own oil or gas properties. It is clear, however, that the parent corporation will not qualify as a principal business corporation merely because its principal assets are the shares of a resource based subsidiary, even though the parent corporation effectively controls the day to day management of the subsidiary. ${ }^{34}$

A question that remains unanswered is when the corporation must be a principal business corporation in order to obtain preferential treatment in the deduction of drilling exploration expenses incurred by it. In $M W A$ Gas and Oil Limited v. M.N.R. ${ }^{35}$ the Court held that a corporation need not be a principal business corporation throughout the year in which the deduction of exploration expenses are claimed. ${ }^{36}$

Although it is not clear whether the corporation must also be a principal business corporation when the expenses are being incurred or merely when it seeks to deduct the expenses in calculating its income, the prevailing view seems to be that it must be a principal business corporation at some time during the year in which the expenses are claimed. Whether it is a principal business corporation when the expenses are incurred is apparently irrelevant.

\section{Classification of Expenditures}

Having ascertained whether the taxpayer is a principal business corporation, the deduction of expenses incurred in the process of acquiring and developing oil and gas properties will vary mainly according to the time when they were incurred. Generally the expenses can be treated in three main categories, namely, expenses incurred before 1972 and deductible under the Income Tax Application Rules, expenses incurred after December 31, 1971 but before the major revisions to the Act affective from May 6, 1974 and expenses incurred after May 6, 1974. The Act and the Income Tax Application Rules provide by relatively obscure language the order in which the deductions are to be claimed. ${ }^{37}$

While all expenses except the deductions in respect of Canadian development expenses incurred after May 6, 1974 and Canadian exploration expenses incurred by a taxpayer other than a principal business corporation after May 6, 1974 are deductible to the extent of income, a deduction to the full extent of income need not be claimed in respect of certain expenses as, for example, the deduction by an individual of Canadian exploration and development expenses against income other than oil and gas income. Consequently, while the general rule is that an expense is deductible in the year claimed to the extent not deductible in previous years, a statement to the effect that such expenses must always be claimed in any year, while usually correct, is too broadly worded to be of universal application.

34. Sogemines Development Company Limited v. M.N.R. [1972) C.T.C. 284; 72 D.T.C. 6254 (F.C.T.D.); Aff d. [1973] C.T.C. 383; 73 D.T.C. 5304 (F.C.A.).

35. [1974] C.T.C. 140; 74 D.T.C. 6123 (F.C.T.D.).

36. For a discussion of this question see Rae, Current Developments in Oil and Gas Taxation (1975) 23 Alta. Law Rev. 46 at 49 .

37. Because of the relative obscurity of the language, the exact order of deductions is largely a matter of opinion. As a rule of thumb, however, it can usually be assumed that, where the deduction of expenses is limited to certain types of income, these expenses will be deductible to the extent of such income prior to the deduction of other expenses. Otherwise the expenses are generally deductible on a chronological basis with the earliest expenses being deductible first. Where, however, an expense is one that must be specifically claimed by the taxpayer it will usually take precedence over other expenses. 


\section{(a) Expenses Incurred Before 1972}

Corporations that are principal business corporations, as that term is defined relative to the time when such expenses were incurred, may deduct from income the aggregate of drilling and exploration costs including general geological and geophysical expenses incurred after 1948 and before $1972 .^{38}$ Such expenses are generally deductible to the extent of income calculated before any deduction for depletion and less any amounts deducted in respect of dividends received from Canadian corporations and controlled foreign affiliates..$^{39}$

Drilling and exploration expenses ${ }^{40}$ for this period are defined to include expenses incurred in Canada in or in respect of drilling or converting a well for the disposal of waste liquids from a petroleum or natural gas well, drilling for water or gas for injection into a petroleum or natural gas well and drilling or converting a well for the injection of water or gas to assist in the recovery of petroleum or natural gas from another well.41

Taxpayers other than principal business corporations who are members of associations, partnerships or syndicates formed for the purpose of exploring or drilling for petroleum or natural gas ${ }^{42}$ are entitled to deduct their allocable shares of such drilling and exploration expenses incurred by them after 1948 and before 1972 to the extent of the taxpayer's income from all such similar ventures of which he is presently a member. Such taxpayers may also deduct drilling and exploration expenses incurred by them personally and in the case of individuals, their shares of such expenses incurred by such oil and gas

38. ITAR 29(1, (3) and (4).

39. The rule that expenses are deductible to the extent of income without the deduction for depletion but after the deductions allowed under sections 112 and 113 is generally applicable to all expenses. The specific provision will also usually provide that the expenses are deductible to the extent of income minus the deductions allowed by other provisions of the Act. For example. ITAR 29(3) provides that expenses are deductible to the extent of the corporation's income for the year if no deduction were allowed under section 65 of the amended Act and if no deduction were allowed under ITAR 29 or section 66 of the amended Act. minus the deductions allowed for the year by subsections (1), (2), (25) and (29) of ITAR 29, subsections 66 6 (6) and (7) of the amended Act and sections 112 and 113 of the amended Act.

The effect of this language is that the expenses in question will be claimed before any deduction for depletion (section 65) or for expenses incurred prior to 1972 (ITAR 29) or for expenses incurred after 1971 and before May 6, 1974 (section 66), and after expenses deductible on a limited basis under the predecessor/successor rules and against qualifying income before 1972 (ITAR 29(25) and (29)) and after 1971 (subsection 66(6) and (7)), expenses incurred before 1952 (ITAR 29(1) and (2)) and deductions in respect of intercorporate dividends (sections 112 and 113) that are effectively tax free in any event.

Technically, the section should also contain a provision to the effect that Canadian exploration expenses incurred by the corporation and deductible under section 66.1 of the Act will not be deductible in computing the income in question. This is apparently an oversight.

40. In Imperial Oil Limited v. M.N.R. [1959] C.T.C. 29; 59 D.T.C. 1034 (Exch. Ct.) at 37 and 1038 the court said: "Here I should set out what is meant by the terms 'exploration' and 'development' as they are understood in the industry. Exploration takes two forms, one being primary exploratory work and the other, exploratory drilling. Primary exploratory work is done in an area that has not previously been explored and in which there has not been any clear indication of the presence of oil or gas. It consists essentially of work of a geophysical character, such as seismic, gravity-meter and serial magnetometer surveys, but it also includes work of a geological nature, such as structure test drill surveys, that is to say. shallow subsurface geologic oil investigations designed to show the geological character of the deeper subsurface, and general surface geological surveys. Then, if the geophysical or geological indications so suggest exploratory drilling is done in the hope of finding oil or gas in an area in which it has not previously been found. Then, there may be velocity surveys in holes that may have been drilled in order to determine the velocity of sound waves through the rock formations in aid of the interpretation of such seismic surveys as have been made. In addition to its aerial surveys the appellant did some photogeology work, that is to say, it took some aerial photographs of the ground in order to assist in the determination of its geological character. Photogeology work is a reconnaissance guide to surveys.

If a well is drilled and produces oil or gas it is called a discovery well. In the area of such discovery the development section then takes over and development drilling is done in it for the purpose of developing whatever oil reserves there may be in it."

41. ITAR $29(27)$ was presumably enacted to extend the definition of drilling and exploration expenses to those activities that would not otherwise be treated as "exploration".

42. ITAR $29(9)$ and (10). 
joint ventures after April 10, 1962 and before 1972 to the extent of their oil and gas income.

Certain capital costs incurred in respect of the acquisition after April 10,1962 and before 1972 of the right, licence or privilege to explore for, drill for or take petroleum or natural gas or related hydrocarbons will be treated as drilling and exploration expenses to the extent that payments were made before 1972 and as a Canadian exploration and development expense to the extent the payments were made after 1971. The eligible expenses are limited, however, to amounts expended for rights acquired pursuant to an agreement, contract or arrangement under which there was not acquired any other right over, or in respect of, the land in respect of which such right, licence or privilege was acquired, except the right to explore for, drill for, or take materials or substances produced in association with the oil or gas (except coal) or to enter upon it and occupy so much of the land as may be necessary for the purpose of exploiting such rights. ${ }^{43}$

Payments to the Crown (other than a rental or royalty) for the right to explore for oil and gas on a specified parcel of land, such as for a licence, permit or drilling reservation or for petroleum and natural gas lease acquired before April 11, 1962 by a principal business corporation or an oil and gas joint venture, will be deductible if the rights so acquired are surrendered without any payment being received on the surrender. The deduction arises in the year in which the surrender is effected and will be treated as a drilling and exploration expense or a Canadian exploration and development expense as the case may be.44

\section{(b) Canadian Exploration and Development Expenses}

(Expenses Incurred After 1971 and Before May 7, 1974)

Canadian exploration and development expenses are deductible by a principal business corporation to the extent of its income for the taxation year. ${ }^{45}$ Undeducted expenses may be carried forward indefinite-

43. ITAR 29(14) provides as follows: "Where an association, partnership or syndicate described in subsection (9) or a corporation or individual has, after April 10, 1962 and before 1972, acquired under an agreement or other contract or arrangement a right, licence or privilege to explore for, drill for or take in Canada petroleum, natural gas or other related hydrocarbons (except coal) under which agreement contract or arrangement there was not acquired any right to, over or in respect of the land in respect of which such right, licence or privilege was so acquired except the right: (a) to explore for, drill for or take materials and substances (whether liquid or solid and whether hydrocarbons or not) produced in association with the petroleum, natural gas or other related hydrocarbons (except coal) or found in any water contained in an oil or gas reservoir, or (b) to enter upon, use and occupy so much of the land as may be necessary for the purpose of exploiting such right, licence or privilege, an amount paid before 1972 in respect of the acquisition thereof shall, for the purposes of subsection (4), (7), (10), (11) and (12), be deemed to be a drilling or exploration expense as or in respect of exploring or drilling or petroleum or natural gas in Canada incurred at the time of such payment and an amount paid after 1971 in respect of the acquisition thereof shall, for the purposes of the amended Act, be deemed to be Canadian exploration and development expenses (within the meaning assigned by subsection 66(15) of the amended Act) incurred at the time of such payment."

See Marflo Drilling Company Limited (formerly Marflo Oils Limited) v. M.N.R. [1967] C.T.C. 281; 67 D.T.C. 5196 (Exch. Ct.); New Continental Oil Company of Canada Limited v. The Queen [1976] C.T.C. 44; 76 D.T.C. 6038 (F.C.T.D.).

It is noted that the costs are deductible essentially on a cash basis so that payments made under an instalment sale agreement after 1971 are deductible as Canadian exploration and development expenses in the year in which they are paid. In fact, amounts paid after May 6, 1974 will, it seems, continue to be treated as Canadian exploration and development expenses.

44. ITAR 29(21). It would appear that the cost of surrendered rights will be treated as a Canadian exploration and development expense even if lands are surrendered after May 6. 1974.

45. Subsection 66(1) provides as follows: "A principal-business corporation may deduct, in computing its income for a taxation year, the lesser of: (a) the aggregate of such of its Canadian exploration and development expenses as were incurred by it before the end of the taxation year. to the extent that they were not deductible in computing income for a previous taxation year, and (b) of that aggregate, an amount equal to its income for the taxation year if no deductions were allowed under this section or section 65 or 66.1 , minus the deductions allowed for the year by subsections (2), (4), (6) and (7) and by sections 112 and $113 . "$ 
ly but must be deducted to the full extent possible in any particular year. ${ }^{46}$ Other taxpayers are, however, limited in their deduction of such expenses to the greater of $20 \%$ of the undeducted balance in any year and the taxpayer's income from the production of oil or gas from wells, or minerals from mines in Canada, royalties payable in respect of an oil or gas well or mine in Canada and any amount included in his income for the year from the disposition of Canadian resource property (less the amount of any reserve claimed in respect of the unpaid portion of such proceeds). ${ }^{47}$

The taxpayer who is not a principal business corporation may claim an amount up to $20 \%$ of the balance of undeducted expenses but must deduct the full amount of such percentage of expenses to the extent that he has qualifying oil and gas income. Thus, such expenses will be deductible to the extent of qualifying oil and gas income and any excess may at the option of the taxpayer be deducted against other income provided the total amount claimed does not exceed $20 \%$ of the undeducted balance of expenses. If such expenses are deductible in a particular year either because there was qualifying oil and gas income or because the expenses were claimed as a deduction against other income, they are not deductible in a subsequent year.

"Canadian exploration and development expenses incurred by a taxpayer" is defined by paragraph 66(15)(b) of the Act. ${ }^{48}$ In the oil and gas context clauses (i), (iii) and v.1) define the class of deductible expenses. Specifically, clauses (i), (iii) and (v.1) bring within the expression Canadian exploration and development expenses incurred by a taxpayer:

(a) any drilling or exploration expenses including any general geological or geophysical expense incurred by him after 1971 on or in respect of exploring for petroleum or natural gas in Canada;

(b) the cost to him of a Canadian resource property acquired by him; and

(c) an annual payment made by the taxpayer for the preservation of a Canadian resource property if it had been acquired by the taxpayer after 1971 .

The definition of drilling and exploration expenses has not changed materially since it was introduced and is broadly construed by the Department of National Revenue. A departure from the system as it was prior to 1972 is that the cost of acquiring a Canadian resource property

46. This results from the requirement that the expenses are only deductible in a particular year to the extent that they were not deductible in a previous taxation year. See Sogemines Development Co. Lid. v. M.N.R., supra, $\mathbf{n}$. 34 .

47. I.T.A. subsection 66(3).

48. I.T.A. paragraph $66(15)(b)$ provides as follows: “'Canadian exploration and development expenses' incurred by a taxpayer means any expense incurred before May 7, 1974 that is: (i) any drilling or exploration expense, including any general geological or geophysical expense, incurred by him after 1971 or in respect of exploring or drilling for petroleum or natural gas in Canada, (ii) any prospecting, exploration or development expense incurred by him after 1971 in searching for minerals in Canada, (iii) the cost to him of any Canadian resource property acquired by him, (iv) his share of the Canadian exploration and development expenses incurred after 1971 by any association, partnership or syndicate in a fiscal period thereof, if at the end of that fiscal period he was a member or partner thereof, ( $v$ ) any expense incurred by the taxpayer after 1971 pursuant to an agreement with a corporation under which the taxpayer incurred the expense solely in consideration for shares of the capital stock of the corporation issued to him by the corporation or any interest in such shares or right thereto, to the extent that the expense was incurred as or on account of the cost of (A) drilling or exploration activities, including any general geological or geophysical activities, in or in respect of exploring or drilling for petroleum or natural gas in Canada, (B) prospecting, exploration or development activities in searching for minerals in Canada, or (C) acquiring a Canadian resource property, and (v.1) any annual payment made by the taxpayer for the preservation of a Canadian resource property or property that would have been a Canadian resource property if it had been acquired by the taxpayer after 1971, but, for greater certainty, does not include (vi) any consideration given by the taxpayer for any share or any interest therein or right thereto, except as provided by subparagraph (v), or (vii) any expense described in subparagraph (v) incurred by another taxpayer to the extent that the expense was, by virtue of subparagraph (v), a Canadian exploration and development expense of that other taxpayer." 
is deductible on a basis equivalent to drilling and exploration expenses. A Canadian resource property is defined in paragraph $66(15)(c)$ as follows:

'Canadian resource property' of a taxpayer means any property acquired by him after 1971 that is,

(i) any right, licence or privilege to explore for, drill for, or take petroleum, natural gas or other related hydrocarbons in Canada,

(ii) any right, licence or privilege to prospect, explore, drill, or mine for, minerals in a mineral resource in Canada,

(iii) any oil or gas well situated in Canada,

(iv) any rental or royalty computed by reference to the amount or value of production from an oil or gas well, or a mineral resource, situated in Canada,

(v) any real property situated in Canada the principal value of which depends upon its mineral resource content (but not including any depreciable property situated on the surface of the property or used or to be used in connection with the extraction or removal of minerals therefrom) or

(vi) any right to or interest in any property (other than property of a trust) described in any of subparagraphs (i) to (v) (including a right to receive proceeds of disposition in respect of a disposition thereof).

As a result the costs of most oil and gas properties acquired after December 31, 1971 and before May 7, 1974 are deductible as Canadian exploration and development expenses. Subparagraph (vi) of paragraph 66(15)(c) was amended in 1974 by the addition of the words "(other than property of a trust)" and the words "(including a right to receive proceeds of disposition in respect of a disposition thereof" ". 49 The former amendment is apparently designed to avoid the effects of a ruling issued by the Department of National Revenue to the effect that units in a unit trust listed on the Toronto Stock Exchange, the principal assets of which were mineral resource properties, were to be treated as Canadian resource properties..$^{50}$ The purpose of the latter amendment is not clear.

The consequences of the amendments are somewhat more extensive than was apparently intended. For example, whenever assets are held in trust, the purchaser will be required to enquire as to the nature of the trust instrument under which the assets are held. If it is a bare trust it will be ignored for tax purposes ${ }^{51}$ and the property will be treated as a Canadian resource property. If the trust imposes active duties on the trustee the trust may be recognized for tax purposes in which case the property will be treated as either a capital or income interest in a trust. It should also be noted that such interests acquired before November 19, 1974 will be a resource property if a deduction has been claimed in respect of the property for a taxation year ending before 1976 under section 66 or 66.2 of the Act.

(c) Canadian Exploration Expense and Canadian Development Expense

(Expenses Incurred After May 6, 1974)

The Budget of May 6, 1974 changed substantially the basis upon which expenditures incurred in the exploration for and development of oil and gas properties could be deducted. The amendments reflected a change in the basic philosophical attitude of government towards the deduction of these expenditures. In this regard the Minister of Finance stated: 
It is also apparent that the petroleum and mineral resource industries in Canada have reached sufficient maturity that the existing tax incentives are more generous than is needed to encourage continuing development. Accordingly I am also proposing to cut back immediately on some of the existing incentives. Henceforth depletion can be claimed only if it is earned and only up to an annual maximum rate of $25 \%$ of production income rather than 33-1/3\%. Canadian exploration and development expenditures have in the past been deductible immediately. If incurred in the future they will be amortized at a rate of $30 \%$ calculated on the diminishing balance basis. ${ }^{52}$

Thus, on the basis of this speech, exploration and development expenditures were to be capitalized and amortized in essentially the same way as capital expenditures on depreciable equipment were depreciated. No distinction was made in the treatment of principal business corporations and other taxpayers and, more significantly, exploration expenditures were to be deductible on the same basis as development expenditures.

The situation improved when the government reintroduced its proposed fiscal measures on November 18, 1974. In his speech to the House of Commons, Mr. Turner said:

Second, Mr. Speaker, in the May 6 Budget I proposed that the rate of write-off for expenditures on exploration and development for both petroleum and minerals be reduced from $100 \%$ to $30 \%$. At the time I felt that such a lower rate was appropriate in light of the existing circumstances of the natural resource industries. However, I have been persuaded by the arguments presented to me over the past several months by both large and small companies that exploration in Canada is becoming ever more expensive and risky. It is difficult, particularly for smaller companies to borrow exploration capital and therefore there is a heavy reliance on internally generated funds. On the other hand, expenditures on development are more similar to the capital expenditures incurred by other industries. Hence, for both petroleum and minerals I am proposing to restore the $100 \%$ write-off for exploration expenditures but to retain the proposed $30 \%$ rate of write-off for development outlays. ${ }^{53}$

\section{Exploration and Development Defined}

As a result of this change in policy, the distinction between exploration expenses and development expenses is now critical. Canadian exploration expenses, as defined in the amended Act, generally reflect the inherent exploratory characteristics of the expenditure. Thus, all expenses incurred for the purpose of determining the existence, location, extent or quality of an accumulation of petroleum or natural gas in Canada, including general geological, geophysical or geochemical expenses will be treated as exploration expenses. ${ }^{54}$ The costs of drilling oil or gas wells will also be treated as exploration expenses if the well is completed within six months after the end of the year in respect of which the deduction is being claimed and it is determined either that it is not reasonable to expect the well to come into production in commercial quantities within twelve months of its completion, or that it is the first well capable of commercial production from an accumulation of petroleum or natural gas not previously known to exist. ${ }^{55}$

The costs incurred in drilling other wells will be treated as development expenses. ${ }^{56}$ While expenses incurred in drilling an oil or gas well will necessarily be treated as development expenses if the well is not completed within six months of the end of the year in which the

52. House of Commons Debates, 2nd Sess. 29th Parl. at 2080.

53. House of Commons Debates, 1st Sess. 30th Parl. at 1425.

54. I.T.A. subparagraph $66.1(6)(a)(i i)$.

55. I.T.A. subparagraph 66.1(6)(a)(ii).

56. I.T.A. subparagraph $66.2(5)(0)(i)$. 
expenses are incurred, the expenses will be reclassified as an exploration expense in a subsequent year if, within six months after the end of that year, the well is completed and it is determined to be an exploratory well.57 Reclassification of the expense is by way of a reduction in the balance of a cumulative Canadian development expense of the taxpayer for the year in which the reclassification takes place and recognition of the expense as a Canadian exploration expense of the taxpayer for that same year.

There are, as might be anticipated, a number of interpretative issues arising out of the legislation. For example, in characterizing the well as an exploratory or development well, a judgment must be made as to whether production is from "an accumulation of petroleum or natural gas . . . not previously known to exist".

The point in time when a well comes into commercial production will likely be determined by industry practice but it is also susceptible to manipulation. Discovery of oil or gas in paying quantities will not necessarily mean that the well will come into production within one year of its completion. It will be impossible to produce the well until the necessary gathering system is in place, an event that will likely be subject to the control of the well operator. It may therefore be possible, by deferring installation of the necessary equipment, to characterize drilling expenses as exploration expenses.

An interesting issue has arisen as to whether a test well is in fact an "oil or gas well" or whether it is an operation the cost of which will be treated as a geological expense, in which event it will not be subject to the timing rules relating to the characterization of expenses incurred in drilling an oil or gas well. The argument that these wells are really geological expenses is persuasive and has apparently been accepted by the Department of National Revenue for assessing purposes. The characterization will, it seems, depend on whether the well was drilled with an intention to produce oil or gas if found, in which case it is an "oil or gas well", or whether the sole purpose of drilling was the obtaining of information, in which case the well is not an "oil or gas well".

The other major Canadian development expense is the cost of acquisition of a Canadian resource property. Specifically excluded however is the cost of a property acquired from a Crown agency.58 Disallowance of the cost of a Canadian resource property acquired from a Crown agency was obviously designed to foreclose the possibility of a province effectively avoiding the rules relating to the disallowance of Crown royalties by selling the resources for a series of payments payable over a period of time. Recognition was provided for the deduction of first time bonus payments for the acquisition of Crown leases.5 The disallowance of any deduction for the cost of acquisition of Canadian resource properties acquired from Crown agencies has, however, caused considerable concern in the industry in light of the increasing number of "commercial" corporations that would be treated as Crown agencies under the Act. A strict interpretation of the provisions disallowing the deduction of the cost of acquisition of Canadian resource properties from Crown agencies would obviously severely restrict the ability of these 
corporations to deal in the commercial sector. The Department of National Revenue has therefore applied the rules liberally and is relying on the allowance of a deduction for first time payments for rights to explore for and take petroleum as the basis for the deduction of such costs.

Bill C-97 will, if enacted, expressly permit the cost of acquisition of all Canadian resource properties acquired by the taxpayer after May 6, 1974 to be treated as a Canadian development expense whether or not acquired from a Crown agency.

\section{The Cumulative Accounts}

In addition to drawing a distinction between Canadian exploration expenses and Canadian development expenses, the 1974 legislation introduced the concept of the "cumulative" expense. The cumulative concept is very similar to the capital cost allowance system applicable to depreciable property. It is designed to reflect on a completely current basis all the expenses incurred by the taxpayer after May 6, 1974, any expenses that have been recovered by him through reimbursement or otherwise, and any deductions that have been claimed by him in calculating his income for previous taxation years. If the account is in a positive balance at the end of the year, the taxpayer may deduct an amount in respect thereof which will depend upon the character of the taxpayer as a principal business corporation or otherwise, and whether the item is in the exploration or development category.

If the account is in the negative balance at the end of the year the negative amount must be included in the taxpayer's income for the year under paragraph $59(3.2)(b)$ or (c) of the Act.

Specifically, a taxpayer's cumulative Canadian exploration expense $e^{60}$ will be increased by:

(a) the Canadian exploration expenses that are incurred by him or considered to have been incurred by him before that time;

(b) any amounts that have been included in his income as a result of the account being in a negative balance for taxation years ending before that time;

(c) certain interest payments paid to Her Majesty in respect of the repayment of assistance provided under specific regulations; and

(d) certain amounts in respect of the reimbursement of exploration expenses that have been established to have become a bad debt;

and will be decreased by:

(e) any amount deducted or deductible as the case may be in computing the taxpayer's income for a taxation year ending before that time in respect of his cumulative Canadian exploration expense;

(f) any amount that became receivable by him before that time in respect of the reimbursement of Canadian exploration expenses previously incurred by him;

(g) amounts paid to him after May 6, 1974 and before that time under the Northern Mineral Exploration Assistance Regulations in respect of the Northern Mineral Grants Program or pursuant to any agreement entered into between the taxpayer and $\mathrm{Her}$ 
Majesty in Right of Canada under the Mineral Grants Program or the Development Program for the Department of Indian Affairs and Northern Development to the extent that such amounts have been expended by the taxpayer on account of Canadian exploration and development expenses or Canadian exploration expenses incurred by him; and

(h) any amounts received in respect of the reimbursement of expenses where the receivable had previously been established to have become a bad debt and treated as a debt item in calculating the Canadian exploration expense.

Similarly, a taxpayer's cumulative Canadian development expense ${ }^{61}$ will be increased by:

(a) any Canadian development expense incurred by him or considered to have been incurred by him before that time;

(b) any amounts which will be required to be included in income for previous taxation years as a result of the cumulative Canadian development expense being in a negative balance;

(c) amounts that are receivable by him and would otherwise be treated as a credit to the cumulative Canadian development expense but that have been established to have become a bad debt;

and will be decreased by:

(d) any amount deducted by him in computing his income for a taxation year ending before that time in respect of his cumulative Canadian development expense;

(e) any amount that became receivable by him after May 6, 1974 in respect of the disposition of a Canadian resource property or a property that would have been a Canadian resource property had it been acquired by him after 1971;

(f) any amount that became receivable by him for that time in respect of the reimbursement of expenses that were treated as Canadian development expenses and previously added to the Canadian development expense;

(g) expenses incurred in drilling oil and gas wells which were previously treated as Canadian development expenses but that have been reclassified as Canadian exploration expenses;

(h) any payment made on account of amounts previously treated as bad debts referred to in paragraph (c) above; and

(i) all amounts paid to the taxpayer before that time under the Northern Mineral Exploration Assistance Regulations in respect of the Northern Mineral Grants Program or pursuant to any agreement entered into between the taxpayer and Her Majesty in Right of Canada under the Northern Mineral Grants Program or the Development Program of the Department of Indian and Northern Affairs to the extent that the amounts have been expended by the taxpayer as or on account of Canadian development expenses incurred by him.

If either account is in a negative balance at the end of the taxation 
year the amount thereof will be included in the taxpayer's income pursuant to $59(3.2)(\mathrm{c})$ of the Act. ${ }^{62}$

It is important to recognize that the proceeds of sale of a Canadian resource property are recognized in a taxpayer's cumulative Canadian development expense. In effect the proceeds of sale are treated as a recovery of Canadian development expenses. This is significant in that it permits any previously undeducted Canadian development expenses and any such expenses incurred in the year in which the sale takes place to be applied fully against the proceeds of the sale. As a result, only the resulting negative balance of the cumulative Canadian development expense, if any, need be recognized as income in the year of sale.

\section{Deductions}

If the account is in a positive balance the amount or a portion thereof is deductible. Taxpayers, other than principal business corporations, may deduct up to $30 \%$ of the cumulative Canadian exploration expense at the end of the year, ${ }^{63}$ and up to $30 \%$ of the cumulative Canadian development expense at the end of the year. ${ }^{64}$ The deduction is optional by the taxpayer and failure to deduct in one year will not preclude his claiming a deduction in a subsequent year subject always to the $30 \%$ limitation.

Principal business corporations may deduct their cumulative Canadian development expense on the same basis as other taxpayers but are required to deduct the full amount of their cumulative Canadian exploration expense to the extent of their income for the year. ${ }^{65}$

\section{Bill C-97}

The amendments contained in Bill C-97, if enacted, will introduce new rules relating to the deduction of Canadian exploration expenses by taxpayers who are not principal business corporations. For taxation years ending after May 25, 1976, individuals and corporations, other than principal business corporations, will be entitled to deduct Canadian exploration expenses to the extent of the greater of $30 \%$ of the cumulative Canadian exploration expense at the end of the year, and the amount of the qualifying oil and gas income for the year. In addition, however, Canadian exploration expenses incurred after May 25, 1976 and before July, 1979, may be deducted without restriction against income from all sources to the extent of the taxpayer's cumulative Canadian exploration expense at the end of the year.

It would appear that the proposal is considerably more attractive than anticipated. For example, unlike the deduction of Canadian exploration and development expenses under section 66(3) of the Act, the taxpayer is not required to deduct the expense to the extent of oil and gas income in a particular year. While not an insignificant advantage to the corporate taxpayer, this is extremely valuable to individuals facing progressive rate of taxation. For example, an individual taxpayer could be in a particular year choose not to deduct any Canadian exploration

62. I.T.A. subsection 66.1(1) and I.T.A. subsection 66.2(1).

63. I.T.A. subsection 66.1(3).

64. I.T.A. subsection $66.2(1)$.

65. I.T.A. subsection 66.1(2): "A taxpayer that is a principal-business corporation shall deduct in computing its income for a taxation year an amount equal to the lesser of (a) its cumulative Canadian exploration expense at the end of the year, and (b) its income for the year if no deductios were allowed under this subsection or section 65, minus the deductions allowed for the year by subsections (4) and (5) and sections 66, 112 and 113." 
expenses, thereby maximizing the amount of deduction available in respect of his resource allowance while at the same time preserving such deductions for application against income in a subsequent taxation year that is not eligible for the resource allowance.

It would appear as well that the taxpayer may claim the full amount of his cumulative Canadian exploration expense to the extent of oil and gas income without being required to apply the expenses incurred during the qualifying period. Thus, it is arguable that expenses incurred prior to May 25, 1976 may be fully deducted against oil and gas income, while at the same time expenses incurred during the qualifying period may, to the extent of the balance of cumulative Canadian exploration expenses of the taxpayer, be applied against unrelated income.

However, if a taxpayer has unused Canadian exploration and development expenses which are deductible in full against Canadian oil and gas income under section 66(3) of the Act, it would appear that these expenses will be deductible against oil and gas income only to the extent that no claim is made in respect of the taxpayer's cumulative Canadian exploration expense. If a taxpayer deducts an amount in respect of his cumulative Canadian exploration expense it will reduce the amount of qualifying oil and gas income against which the exploration and development expenses may be claimed. Consequently, the taxpayer will be unable to take full advantage of the effects described above until the taxation year after which his Canadian exploration and development expenses have been exhausted.

In addition, Bill C-97 would propose to introduce an amendment to subparagraph $66.1(6)(\mathrm{a})(\mathrm{vii})$ and subparagraph $66.2(5)(\mathrm{a})(\mathrm{viii})$ to the effect that where expenses incurred by the taxpayer have been subsidized by assistance or benefits received from a government, municipality, or other public authority, whether it is a grant, subsidy, forgiveable loan, deduction from royalty, or tax credit, etc., such amounts shall not be applied to reduce the amount of the taxpayer's Canadian exploration expense or Canadian development expense respectively. This amendment is aimed at the various exploratory incentive provisions in the western provinces and is designed to ensure that the effect of those incentives is not eroded through the disallowance of a deduction as might be the case at common law. ${ }^{66}$

\section{SPECIAL RULES}

\section{Associations, Partnerships and Syndicates}

Under Income Tax Application Rule 29(9) and (10) a member of an association, partnership or syndicate formed for the purpose of exploring for, or drilling for, petroleum or natural gas ${ }^{67}$ may, in computing his income therefrom, deduct his share ${ }^{68}$ of drilling and exploration

66. Okalta Olis Limited v. M.N.R. [1955] C.T.C. 271; 55 D.T.C. 1176 (S.C.C.). In order to be treated as a subsidiary there must be a direct relationship between the grant and the expense incurred. St. John Dry Dock \& Shipbuilding Company Limited v. M.N.R. [1944] C.T.C. 106; 2 D.T.C. 663 (Exch. Ct.); Attorney. General for Manitoba v. San Antonio Gold Mines Limited [1951] C.T.C. 81 (Man. C.A.).

67. The purpose for which the group was formed rather than the character of any business carried on by it in a given taxation year. In this sense the qualification differs from the qualification of a corporation where the principal business corporation continues to be relevant in determining the deductibility of expenses. See for example M.W.A. Gas and Oil Limited v. M.N.R., supra, n. 35. For a discussion of the meaning of the expression "association partnership or syndicate" see Bell, R. D., Taxation of Mining and Petroleum (1974) 12 Alta. L. Rev. 36.

68. The Department of National Revenue has interpreted the words "his share" of expenses "incurred" to require that a taxpayer have actually contributed to the drilling and exploration expenses of the group. It would therefore seem impossible to allocate expenses for income tax purposes other than on the actual sharing arrangement. See in this regard Samuel Weier v. M.N.R. (1960) 25 Tax A.B.C. 373. 
expenses incurred by all such associations, partnerships or syndicates, while he was a member thereof after 1948 and before 1972 , to the extent that it was not previously deductible by him in calculating his income for a previous taxation year.

The statute requires that the expenses be incurred by a qualified association, partnership or syndicate while the taxpayer was a member thereof and that they be deducted against income from similar associations, partnerships or syndicates of which he is currently a member. There is apparently no requirement that the partnership of which the taxpayer is currently a member be the partnership that in fact incurred the expense. Thus, provided the taxpayer has income from qualified partnerships of which he is currently a member, he will be able to deduct expenses incurred prior to 1972 while he was a member of a similar partnership.

It is often necessary to determine whether the deduction of such expenses is governed by ITAR 29(9) or (10) or by other subsections of ITAR 29.69 It is clear that for expenses incurred prior to April 11, 1962 and deductible under ITAR 29(9) an individual or corporation other than a principal business corporation may not deduct such expenses except to the extent of income from qualified joint ventures. However, ITAR 29(12) expressly permits an individual to deduct such expenses incurred after April 10, 1962 that exceed the amounts deductible under ITAR 29(9) and (10) against other oil and gas income.

While it would appear theoretically possible to take the opposite position, ${ }^{70}$ in practice, if the taxpayer would have otherwise been entitled to deduct such expenses had he incurred them personally, he has been allowed to deduct such expenses that exceed the income from qualified joint ventures against other income as it becomes available. As a result, principal business corporations need not in practice draw a distinction as between joint venture operations and operations carried on for their own account in determining whether expenses incurred prior to 1972 are deductible against current income. Individuals and corporations other than principal business corporations must, on the other hand, establish that expenses incurred by them prior to April 11, 1962 are expenses incurred by them as members of a qualified joint venture in order to obtain the deduction thereof. For expenses incurred after April 10, 1962 and prior to 1972 they need only ensure that there is adequate oil and gas income to obtain the deduction of these expenses.

The deduction of Canadian exploration and development expenses by a partner or a member of an association or syndicate is permitted by virtue of the inclusion in the definition of Canadian exploration and development expenses of:

... his [the taxpayer's] share of the Canadian exploration and development expenses incurred after 1971 by any association, partnership or syndicate in a fiscal period thereof, if at the end of that fiscal period he was a member or partner thereof.

Unlike the Income Tax Application Rules which only require that the taxpayer be a member of the group when the expenses are incurred by it, subparagraph $66(15)(b)(i v)$ requires that a taxpayer be a member of the

69. ITAR 26 (31) expressly recognizes this possibility.

70. It is arguable that from the express provision in ITAR 29(12)(a)(ii) permitting an individual to deduct his share of group expenses that in the year exceeds the amount deductible under $26(9)$ and (10) one may draw the inference that in the absence of such a provision for corporations the deduction of such expenses by any corporation is prohibited. 
group at the end of its fiscal period during which the expenses were incurred. ${ }^{71}$ Although partnerships are expressly recognized by the amended Act, associations and syndicates have no status under the statute. Thus, while there is a technical requirement that a taxpayer be a member of the association or syndicate at the end of the period during which the expenses were incurred in practice the Department of National Revenue will permit the deduction of such expenses by the taxpayer if they would have otherwise been deductible by him in his own right. In contrast the current administrative practice of the Department of National Revenue is to interpret strictly the requirement that a taxpayer be a member of the partnership at the end of the fiscal year of the partnership during which the expenses were incurred. Consequently, taxpayers will be required to consider carefully whether the arrangement to which they are a party will constitute a partnership for income tax purposes. ${ }^{72}$

As is the case with respect to Canadian exploration and development expenses incurred prior to May 7, 1974, a taxpayer who is a member of an association, partnership or syndicate will be entitled to treat as a Canadian exploration expense or a Canadian development expense his share of Canadian exploration expenses or Canadian development expenses, as the case may be, incurred by the association, partnership or syndicate in its fiscal period if at the end of that fiscal period he was a member thereof. ${ }^{73}$

Such expenses are deductible in the prescribed manner according to the classification and characterization of the particular partner.

It is not the purpose of this paper to deal with the taxation of partnership operations in the oil and gas industry. It is sufficient, however, to point out that, for the purpose of calculating partnership income, the partnership will be treated as a taxpayer and will thus be considered to have cumulative Canadian exploration expense and cumulative Canadian development expense as those terms are defined under section 66.1 and 66.2 respectively. This is the case even though in computing the partnership income no deduction will be permitted in respect of its cumulative Canadian exploration expense or its cumulative Canadian development expense. Each partner will also be treated as having a Canadian exploration expense of a Canadian development

71. Although apparently unintended, it would appear that there is an argument that a more rigorous test is to be met by associations and syndicates than by partnerships in obtaining the deductibility for shared expenses. It seems clear that partnerships are to some extent recognized as entities and as such may in their own right incur expenses. If this is the case then the only requirement for deductibility of Canadian exploration and development expenses by a partner is that he be a member of the partnership at the end of its fiscal period during which the expenses were incurred. The share of expenses that will be deductible will then be determined in accordance with the partnership agreement.

In contrast however, associations and syndicates having no official recognition under the Act, save for this provision must continue to meet the requirements obtaining in respect of taxpayers who are not members of associations. Thus, in order to obtain a deduction for exploration and development expenses incurred as a member of the group a taxpayer must actually have made direct payments with respect to such expenses while a member of the group and must also be a member of the group at the end of the fiscal period when the expenses were incurred.

72. See generally, Bell, R. D., supra, n. 67; Kellough, H. J., The Business of Defining a Partnership Under the Income Tax Act (1974) 22 Can. Tax J. 190, and Interpretation Bulletin IT-90.

73. Subparagraph 66.1(6)(a)(iv) of the Act provides that: "his share of any expense referred to in any of subparagraphs (i) to (iii) incurred by any association, partnership or syndicate in a fiscal period of that association, partnership or syndicate, if at the end of that fiscal period he was a member or partner thereof."

Subparagraph 66.2(5)(a)(v) of the Act provides that: "his share of any expenses referred to in any of subparagraphs (i) to (iv), incurred by any association, partnership or syndicate in a fiscal period of that association, partnership or syndicate, if at the end of that fiscal period he was a member or partner thereof." 
expense to the extent of his share of such expenses incurred by partnerships during a fiscal period thereof if at the end of such fiscal period he was a member or partner therein. It is therefore arguable that both the partnership and the partner will be required to increase their cumulative Canadian exploration expense and their cumulative Canadian development expense by the Canadian exploration expenses and Canadian development expenses incurred by the partnership. As a result the Act would appear to require duplication of the cumulative accounts at the partnership and partner level.

This does not affect the deduction by a partner of expenses incurred by the partnership but will affect the basis upon which the partnership is required to calculate its income, particularly insofar as the income is derived from the sale of Canadian resource properties. As a matter of practice, however, the Department of National Revenue, while recognizing that a partnership does have a cumulative Canadian exploration expense and a cumulative Canadian development expense, takes the position that since such expenses are effectively allocated to the partners under the Act, the partnership may not increase its cumulative expense by the amount of any expenses incurred by it, nor is it required to decrease the cumulative expense by the amount deducted or deductible by the partners in calculating their income for a taxation year ending before the time of calculation. The partnership will, however, be required to adjust the account for other items, such as the recovery of expenses incurred pursuant to subsections 66(12.1) or (12.2) and the proceeds of sale of Canadian resource properties. Where the adjustment results in the partnership's cumulative expense being in a negative balance the amount will be included in partnership income for that year and will be allocated to the partners in accordance with section 96 of the Income Tax Act. Presumably, the partnership would be required to increase its cumulative expense by the amounts included in income under paragraphs $59(3.2)(\mathrm{b})$ or (c) of the Act. As a concession the Department of National Revenue will, however, permit the taxpayer to allocate the amount included in his income to his personal cumulative expense as if the amount had been realized directly by him. Thus, on the sale of a Canadian resource property by a partnership, while the partnership is required to recognize the proceeds of sale as income pursuant to paragraph $59(3.2)$ (c) of the Act such income is also treated as an adjustment of the partner's cumulative Canadian development expense, to the extent of his share thereof, the effect of which is to permit the partner to deduct the full amount of Canadian development expenses incurred by him prior to that time against the proceeds of sale.

It would appear, however, that in formulating its position the Department of National Revenue has not come to grips with several of the related problems arising from this interpretation of the Act. For example, on an instalment sale of Canadian resource property, the Department of National Revenue ${ }^{74}$ would allocate to the partner's cumulative Canadian development expense his share of the proceeds of sale net of any deduction allowed in respect of unpaid amounts. It would therefore appear to follow that all other expenses properly deductible in computing the partnership income, such as interest expense, operating expenses and resource allowance, must be deducted from the amount 
included in computing the partnership's income pursuant to paragraph $69(3.2)(\mathrm{c})$, before allocation thereof to the respective partners. The effect, of course, is to reduce the advantage otherwise available in deducting Canadian development expenses to the full extent possible against proceeds of sale of Canadian resource properties.

\section{(a) Joint Exploration Corporations}

Where a taxpayer is a shareholder of a joint exploration corporation the Act permits the deduction by him of expenses incurred by the joint exploration corporation but paid for by the taxpayer. The joint exploration corporation is defined as a principal business corporation that has not at any time since its incorporation had more than ten shareholders (not including any individual holding a share for the sole purpose of qualifying as a director)..$^{75}$

A joint exploration corporation may elect to renounce in favour of another corporation an agreed portion of such of the joint exploration corporation's expenses as were incurred by it during a period before the end of the taxation year throughout which the other corporation was a shareholder corporation to the extent that such expenses have not otherwise been deductible by the joint exploration corporation in computing its income for any taxation year previous to the year which the election is made. ${ }^{76}$

The expenses that are renounced will be deemed to be expenses incurred by the shareholder corporation and will be deducted from the amounts that are deductible or that must be deducted by the joint exploration corporation in calculating its income for the taxation year or subsequent taxation years. Such expenses are deemed to have been incurred by the shareholder corporation. They will also qualify for inclusion in the earned depletion base of the shareholder corporation. ${ }^{77}$

The "agreed portion"78 is essentially the amount of expenses incurred by the joint exploration corporation that have been financed by the shareholder corporation and which the joint exploration corporation has agreed to renounce in favour of the shareholder corporation under the Act less the amount of any such expenses previously renounced by the joint exploration corporation.

It is usually advisable to provide by agreement the basis upon which the joint exploration corporation will incur its exploration and development expenses and the basis upon which the expenses will be funded by the shareholder corporation. As a matter of practice, however, the agreement is not essential and the Department of National Revenue will allow such expenses to be renounced by the joint exploration corporation to its parent corporation if the parent has advanced the monies spent by the joint exploration corporation prior to the time in which they were incurred.

It is clear that the expenses must be incurred during a period throughout which the parent corporation was holder of the joint exploration corporation. It is also advisable to ensure that the expenses

75. I.T.A. paragraph $66(15 \mathrm{Xg})$.

76. The renunciation of expenses incurred prior to 1972 is governed by ITAR 29(6) and (7). The renunciation of Canadian exploration and development expenses is governed by subsection 66(10) of the Act and the renunciation of Canadian exploration expenses and Canadian development expenses is governed by subsections $66(10.1)$ and $66(10.2)$ respectively.

77. Income Tax Regulations 1205(a)(i)E), 1205(a)(ii)(B) and 1205(a)(iii)(B).

78. I.T.A. paragraph $66(15)(a)$. 
funded by the parent corporation are renounced prior to its ceasing to be a shareholder corporation under the amended Act. Thus, if the shares of a subsidiary that is a joint exploration corporation are to be sold or transferred to an affiliated corporation the subsidiary should renounce any exploration and development expenses prior to the transaction.

There is, however, a good argument to the effect that the joint exploration may renounce expenses to a former shareholder corporation. The amended Act merely provides that the joint exploration corporation may elect to renounce such expenses ". . . as were incurred by it during a period, before the end of a taxation year, throughout which the other corporation was a shareholder corporation". Although the Department of National Revenue apparently takes the position that the "period" referred to in the amended Act must include the end of the taxation year for which the expenses are being renounced it is submitted that the amended Act only provides that the period throughout which the other corporation was a shareholder corporation end prior to the end of the taxation year in which expenses are being renounced. Furthermore, the definition of a shareholder corporation means a corporation that ". . . for the period in respect of which the expression is being applied ..." was a shareholder of the joint exploration corporation and made payments to the joint exploration corporation. The ". . . period in respect of which the expression is being applied ..." is, as submitted, the period during which the expenses were incurred. Therefore, provided the parent corporation was a shareholder at the time it made the advances to the joint exploration corporation and at the time that the expenses were incurred by the joint exploration corporation such expenses will be renounceable to the parent corporation notwithstanding that it is not at the time of renunciation a shareholder of the joint exploration corporation.

To the extent that a shareholder corporation has received property as consideration for any payment to the joint exploration corporation, the adjusted cost base of such property is reduced by that portion of the payment made by the shareholder corporation as may reasonably be considered as being related to the "agreed portion" of the joint exploration and development expenses. ${ }^{79}$ It is not clear whether the Act requires that the adjusted cost base of the shares of the joint exploration corporation be reduced at the time that the payments are made by the shareholder corporation or that it be reduced only upon renunciation of the expenses in favour of the shareholder corporation. As a matter of practice it is understood that the Department of National Revenue does not require an adjustment to the adjusted cost base of the shares until the joint exploration corporation has actually made a renunciation of the expenses. This position is, of course, consistent with their position that the expenses may only be renounced at a time when the shareholder corporation is a shareholder of the joint exploration corporation. If, however, the alternative argument were sustained by a court it is probable the court would also hold that the adjusted cost base of the shares had to be reduced at the time when the payments were made by the shareholder to the joint exploration corporation.

(b) Expenses Incurred for Shares

Where a taxpayer undertakes to incur drilling or exploration expenses

79. I.T.A. paragraph $53(2)(f)$. 
for the benefit of a corporation solely in consideration of the issuance to him of treasury shares of that corporation, the expenses will be deductible according to the character of the expenses involved. ${ }^{80}$

Typically, the taxpayer will enter into an agreement with the corporation under which the taxpayer will undertake to incur the expenses that would otherwise be incurred by the corporation in its operations and the corporation will agree to issue from its treasury a number of shares at an agreed value in proportion of the amount of expenses incurred by the taxpayer. The taxpayer is required to actually incur the expenses. As a result, he must actually do the work involved or be personally liable for any work done by third party contractors. It is not enough to reimburse the corporation for expenses incurred by it.

The cost of the shares acquired under the agreement with the corporation will generally be the amount of expenses incurred by the taxpayer. To the extent the expenses incurred by him are Canadian exploration and development expenses, Canadian exploration expenses or Canadian development expenses, the amended Act requires a reduction in the adjusted cost base by the amount of the expense ${ }^{80 a}$. It is clear that under the scheme of the amended Act the disposition of the shares of the corporation acquired under the foregoing arrangement will be treated as a capital transaction requiring the taxpayer to recognize a capital gain equal to the excess of the proceeds of sale over his adjusted cost base. It has been suggested, however, that as the cost of the shares may reasonably be regarded as having been primarily a Canadian exploration and development expense or a Canadian exploration expense or a Canadian development expense, as the case may be, any proceeds of disposition that become receivable by the taxpayer on the disposition of such shares must be treated as a recovery of expenses pursuant to subsection 66(12.1) of the Act. Clause 26 of Bill C-97, if enacted, would foreclose any possibility of the gain on the sale of such shares being treated as a capital gain. Clause 26 would add section 66.3 as follows:

Any shares of the capital stock of a corporation or any interest in any such shares or right thereto acquired by a taxpayer under the circumstances described in subparagraph 66.1(6)(a)(v) or subparagraph 66.2(5)(a)(v) shall, for greater certainty, be deemed not to be a capital property of the taxpayer but to be inventory of the taxpayer acquired at a cost to the taxpayer of nil.

The new section will be made applicable to shares or a right thereto acquired by the taxpayer after May 25, 1976. The words "for greater certainty" leave open the argument that notwithstanding the fact that section 66.3 is only applicable to shares acquired after May 25, 1976, the disposition of shares acquired under those circumstances before May 25, $1976^{81}$ will be treated as an income transaction. It is unfortunate that the government chose to proceed in this manner. Had it wished to treat the proceeds of disposition of such shares as being on revenue account it

80. I.T.A. subparagraphs $66(15)(b)(v)$ and $66.2(5)(a)(v i)$. ITAR $29(24)$ provides for the deduction of expenses incurred prior to 1972 by a principal business corporation under similar circumstances to those described in paragraph $66(15)(b)(v)$ of the Act. As well, the definition of a "Canadian exploration expense" and a "Canadian development expense" include provisions similar to those described in paragraph $66(15)(b)(v)$.

80a.I.T.A. paragraph $53(2)(e)$. It is also arguable that to the extent expenses were incurred prior to 1972 in consideration of the issuance of shares of the capital stock of the corporation the cost thereof will be reduced for the purposes of calculating the capital gain of a taxpayer. See ITAR 26(13) and I.T.A. paragraph $53(2)(\mathrm{m})$.

81. It should be noted that although the section is said to be applicable in respect of property acquired after May 25, 1976, it would appear to apply to shares acquired after May 25, 1976 under the exercise of options issued prior to May 25, 1976. 
would have been preferable to treat the shares acquired by the taxpayer as being essentially Canadian resource property so that any proceeds of disposition would be applied firstly to reduce the Canadian development expense of the taxpayer and to the extent that any amount had to be included income in respect of the disposition, it would be treated as part of the Canadian resource profits for the purposes of earned depletion.

\section{Predecessor/Successor Corporation Rules}

The Act provides that certain "successor" corporations may deduct exploration and development costs incurred by a "predecessor" corporation where the successor corporation has at any time acquired all, or substantially all, of the property of the predecessor corporation used by it in carrying on its business in Canada. The deduction will be limited to the amount of qualifying oil and gas income earned by the successor corporation from properties in Canada from which the predecessor corporation had, at the time of the acquisition, a right to take or remove petroleum or natural gas. ${ }^{82}$

Whether a corporation has sold all, or substantially all, of the assets used by it in carrying on its business in Canada is essentially a question of fact to be determined by an examination of all the surrounding circumstances. In Wardean Drilling Co., Ltd. ${ }^{83}$ it was held that on the facts at hand, the words "substantially all" meant the substantial portion of the whole business. In that case the taxpayer sold to Scurry Rainbow Oil Limited a specific property in which Scurry Rainbow Oil Limited was particularly interested, at which time the taxpayer owned in addition to that property, a $12 \frac{1}{2} \%$ interest in six Crown leases.

The Minister acknowledged that the sales to Scurry Rainbow Oil Limited did not constitute a sale of all of the property of the taxpayer because it still retained its $121 / 2 \%$ interest in the six Crown leases. He did argue that the sale constituted an acquisition by Scurry Rainbow Oil Limited of all or substantially all of the property used by the taxpayer in carrying on its business in Canada. The taxpayer argued that what is meant by the acquisition by a successor corporation of all or substantially all of the property used by a predecessor corporation carrying on its business in Canada is the acquisition of the business undertaking of the predecessor corporation. The court did not consider this point to be relevant and relied solely upon the literal interpretation of the section, being section $83 \mathrm{~A}$ of the former Act, which is essentially similar to the current legislative provisions. In comparing the properties sold and the properties retained by the taxpayer the court said:

The salient facts which emerge from this comparison of the two properties are that the $5 \%$ interest in leaseholds which was sold to Scurry Rainbow Oil Limited was the sole source of the appellant's revenue. It was an oil producing property on which extensive exploration and drilling had been done. It was considered by Scurry Rainbow Oil Limited to be a desirable property which it sought to acquire and did acquire. There was no exploration or drilling work done on the six Crown leases at any time between their acquisition by the operator in 1957 and the cancellation of those leases in 1966. All that was done by the joint owners, including the appellant, was to pay their proportionate shares of the nominal rent to keep the leases in good standing. The property lay dormant with no effort being made to explore and drill for potential oil or natural gas deposits. When threatened with the revocation of the leases in the event of

82. A successor corporation will also include a second successor corporation: that is a corporation that has acquired all or substantially all of the assets of a corporation that was a successor corporation with respect to the assets of the original predecessor corporation.

83. Wardean Drilling Co., Led. v. M.N.R. [1974] CTC 190; 74 DTC 6164 (E.C.T.D.). 
failure to drill, the leases were allowed to lapse by the joint owners, including the appellant. The appellant offered to sell its interest to Scurry Rainbow Oil Limited but that company declined the appellant's offer.

Without purporting to decide the question whether mere ownership of a minor percentage in these Crown leases is use of that property in carrying on the business of exploring or drilling for oil or natural gas by the appellant the evidence is abundantly clear that this business was not actively engaged in and that the prospect of exploration and drilling thereon was remote.

As a consequence of the foregoing comparison of the facts relating to the two properties owned by the appellant, I am led to the conclusion that the $5 \%$ interest in the leaseholds which was sold by the appellant on April 21, 1964 to Scurry Rainbow Oil Limited was a sale of substantially all of the property used by the appellant in carrying on its business in Canada. ${ }^{84}$

The expenses of the predecessor corporation that will be deductible by the successor corporation will include the predecessor corporation's Canadian exploration and development expenses, ${ }^{85}$ and its Canadian exploration expense ${ }^{86}$ and its Canadian development expense. ${ }^{87}$ Where both corporations are also principal business corporations the amount will also include the drilling and exploration expenses including geological and geophysical costs incurred before 1972 by the predecessor corporation on or in respect of drilling for petroleum or natural gas in Canada. ${ }^{88}$ The expenses are deductible under different sections of the Act and therefore must be segregated to determine the order in which they are to be claimed. ${ }^{89}$

The expenses that are deductible by the successor corporation are those expenses of the predecessor corporation that were not deductible by it in the year in which the acquisition takes place or in previous taxation years but that would have been deductible by the predecessor corporation had its income for those years been adequate. With respect to Canadian exploration expenses and Canadian development expenses the rule appears to be that the cumulative expense of the predecessor corporation that was not deducted in computing its income for the taxation year in which the acquisition took place or for a previous taxation year will be deductible by the successor corporation. The point is unclear however. By way of example, subsection 66.1(4) provides that a predecessor corporation's Canadian exploration expense is deductible by the successor corporation to the extent that it would have been deductible but was not deducted by the predecessor corporation in its taxation year in which the property was acquired by the successor corporation. Unlike subsection 66(6), however, the test is not premised on the predecessor corporation having sufficient income in that year to claim the expense. As the cumulative Canadian exploration expense of a

84. Id. at 200 and 6170 .

85. I.T.A. subsection 66(6).

86. I.T.A. subsection 66.1(4).

87. I.T.A. subsection 66.2(3).

88. ITAR subsection 29(25).

89. The expenses are deductible to the extent of qualifying income in the following order: (a) ITAR subsection 29(29), second successor corporation's expenses incurred prior to 1972; (b) I.T.A. subsection 66(7), second successor corporation's Canadian exploration and development expenses: (c) ITAR subsection 29(25), first successor corporation's expenses incurred prior to 1972; (d) I.T.A. subsection 66(6). first successor corporation's Canadian exploration and development expenses; (e) I.T.A. subsection 66.1(5), 8econd successor corporation's Canadian exploration expense; (f) I.T.A. subsection 66.2(4), second successor corporation's Canadian development expense; (g) I.T.A. subsection 66.1(4), first successor corporation's Canadian exploration expense; (h) I.T.A. subsection 66.2(3), first successor corporation's Canadian development expense. The order of deductions for first and second successor corporations' Canadian exploration and Canadian development expense is not clear under the Act and the order set forth in this respect is arbitrary. For another view see Scace. The Income Tax Law of Canada. 3rd edition, Law Society of Upper Canada, 1976 at 617. 
principal business corporation must be deducted to the extent of income it is impossible that the predecessor corporation would have deductible but undeducted expenses in the year of sale. There is a similar question with respect to the deduction of the cumulative Canadian development expense of a predecessor corporation. However the Department of National Revenue is apparently ignoring these and other legislative deficiencies. ${ }^{90}$ Under its current administrative practice the undeducted cumulative Canadian exploration expense and cumulative Canadian development expense will be deductible by the successor corporation to the extent of qualifying income.

It is generally thought that the expenses deductible by the successor corporation are the expenses that were not deductible by the predecessor corporation in the year in which the transfer of assets takes place. Thus, the predecessor corporation is entitled to claim the expenses against its income for the year, including its income arising on the sale of the properties. Cerainly this point is clear in relation to the Canadian exploration and development expenses of the predecessor corporation. As well this seems to be the view taken by the Supreme Court of Canada in Gustauson Drilling (1964) Ltd. in relation to expenses incurred prior to 1972 under section 83A of the former Act.91 However, in Hargal Oils Limited $^{92}$ the Supreme Court of Canada held that such expenses were not deductible by the predecessor in the year of sale. As the language in ITAR $29(25)$ is essentially the same as section $83 \mathrm{~A}$ it would appear that rule in Hargal Oils Limited still governs. The same issue arises where the expenses are Canadian exploration expenses or Canadian development expenses of the predecessor corporation. The issue turns on the effect of the requirement that such expenses be deductible by the predecessor corporation in computing its income for the taxation year in which the property was acquired by the successor corporation. The legislative intent is in the writer's view obscure and reliance must be placed on the practice of the Department of National Revenue until the language is amended or its meaning explained by competent authority.

The expenses are deductible by the successor corporation to the extent of its income that may reasonably be regarded as attributable to the production of petroleum or natural gas from wells situated on property in Canada from which the predecessor corporation had at the time of acquisition the right to take or remove petroleum or natural gas.

The language is similar to the language contained in paragraphs $12(1)(0)$ and $18(1)(m)$ of the Act and the comments made earlier in relation to those provisions are apposite. In addition it is worth noting that the Act requires that the predecessor corporation have the right to take or remove petroleum or natural gas at the time of acquisition. Thus, income from a well situated on property acquired from a predecessor

90. Another issue relates to the requirement that the cumulative expenses have been deductible but not deducted by the successor corporation in a taxation year prior to the year in which the deduction is claimed. Firstly this language implies that the expenses are deductible only if claimed by the successor corporation. This view is generally inconsistent with the scheme of the Act which requires expenses that are to be deducted by a successor corporation to the extent of qualifying income to be deducted and while it may be acceptable for Canadian development expenses and for Canadian exploration expenses claimed by a taxpayer not a principal business corporation, it is clearly out of line with the treatment of principal business corporations which otherwise must deduct to the extent possible Canadian exploration expenses. A more difficult issue in this context is that of determining what is the first year in which the deduction may be claimed. Clearly it cannot be claimed in the year of acquisition as, prior to that year, the expense was not deductible by the successor corporation, but if not deductible in the year of acquisition is it deductible in the next year?

91. Gustauson Drilling (1964) Limited v. M.N.R., supra, n. 2 at 10.

92. Hargal Oils Limited v. M.N.R. [1965] C.T.C. 50; 65 DTC 5029 (S.C.C.). 
corporation will not qualify if the rights of the predecessor corporation did not include the right to produce oil or gas. For example, if the successor corporation acquires from the predecessor corporation a drilling reservation and subsequently converts the drilling reservation into a lease, the income from the well will not qualify.

The Act does not, however, restrict the income to income that would have been income of the predecessor. Thus, if the successor corporation acquires a part interest in a well from a predecessor corporation and subsequently acquires the balance of the interest in an unrelated transaction it may deduct the expenses against all of the income from the well.

\section{Capitalized Borrowing Costs}

In Sherritt Gordon Mines Ltd.93 it was held that borrowing costs incurred by a taxpayer in connection with the development of a mine but prior to commencement of production could be capitalized and treated as additional costs of depreciable property and development expenses. The 1969 income tax amendments ${ }^{94}$ enacted in the year following the judgment purported to permit a taxpayer to elect to capitalize borrowing costs incurred in respect of the acquisition of depreciable property and exploration and development costs deductible under section $83 \mathrm{~A}$ of the former Act. ${ }^{95}$ Section $85 \mathrm{~J}$ was replaced by section 21 of the amended Act.

Subsection $21(2)^{96}$ provides for the election to treat borrowing costs as Canadian exploration and development expenses, Canadian exploration expenses or Canadian development expenses as the case may be.

Where in a taxation year a taxpayer has used borrowed money for the purpose of exploration or development or the acquisition of property and the expenses incurred by him in respect of exploration or development or the acquisition of property are foreign exploration and development expenses, Canadian exploration expense or Canadian development expense as defined in section $66,66.1$ or 66.2 , as the case may be, if he so elects in prescribed manner on or before the day on or before which he is required by section 150 to file his return of income for the year,

(a) in computing his income for the year and for such of the 3 immediately preceding taxation years as the taxpayer had, if any, paragraphs $20(1)(c),(d)$ and (e) do not apply to the amount or to the part of the amount specified by him in his election that, but for this subsection, would have been deductible in computing his income (other than exempt income) for the year and for those immediately preceding years, if any, by virtue of those paragraphs in respect of borrowed money used for the exploration or development, as the case may be; and

(b) the amount or the part of the amount, as the case may be, described in paragraph (a) shall be deemed to be Canadian exploration and development expense, foreign exploration and development expenses, Canadian exploration expense or Canadian development expense as defined in section $66,66.1$ or 66.2 , as the case may be, incurred by him in the year.

Where the borrowed money is used for the prescribed purpose the taxpayer may elect to treat the borrowing costs ${ }^{97}$ as exploration and

93. Sherritt Gordon Mines Limited v. M.N.R. [1968] C.T.C. 262; 68 D.T.C. 5180 (Fxch. Ct.).

94. Section 85J of the former Act.

95. For a discussion of section $85 \mathrm{~J}$ and its effect relative to the Sherritt Gordon case, see Latimer, Capitalization of Interest, (1969) Can. Tax J. 331.

96. Subsection 21(1) provides for the capitalization of borrowing costs related to the acquisition of depreciable property.

97. Borrowing costs will include interest costs (paragraph $20(1)(\mathrm{c})$ ), compound interest (paragraph $20(1)(\mathrm{d})$ ) and other expenses of borrowing such as standby charges and commitment fees, etc. (paragraph $20(1)(e)$ ). Although the former Act permitted the capitalization of borrowing costs, no express provision is made for an election to be filed in years following 1971 when the borrowed money was used prior to 1972 . It is, however, assumed that subsection 21(4) of the Act will be used in conjunction with ITAR 13/1) to permit such elections to be filed. 
development expenses. The characterization of the capitalized cost will follow the use of the borrowed money so that to the extent such money is used to incur Canadian development expenses, the capitalized costs will be treated as a Canadian development expense.

The election, to be valid, must be made in the year in which the borrowed money is first used for the prescribed purpose although the taxpayer may elect to capitalize borrowing costs incurred for up to three taxation years prior to that time. The taxpayer may elect to capitalize all or a part of the borrowing costs and if only part of the costs are capitalized the balance will be deductible in the year in accordance with the applicable provisions of the Act.

Having capitalized the borrowing costs in the initial year the taxpayer may continue to capitalize borrowing costs on such borrowed money in subsequent years. Subsection 21(4) requires however that the election in subsequent years be made in respect of the total amount that would but for subsection 21(4) have been deductible by him in respect of borrowed money used for the exploration and development. In effect where the costs related to borrowed funds are capitalized the same amount must be capitalized to the extent possible in each subsequent taxation year. If such an election is not filed in any particular year no election may be filed in the following year. Even if an election is filed, but for a lesser amount than is otherwise permissible, while the election is valid in that year, no election is permitted in the following year. Thus in a year following the initial year a taxpayer may reduce the elected amount below the maximum permissible figure only once. Following such reduction no further election is permitted.

\section{DISPOSITIONS OF CANADIAN RESOURCE PROPERTIES}

\section{Resource Property Sales}

The proceeds of disposition of a Canadian resource property are accounted for as a deduction to the taxpayer's cumulative Canadian development expense to the extent that they have become receivable by the taxpayer. ${ }^{97 a}$ An amount becomes receivable at that point in time when there exists a legal, though not necessarily immediate, right to receive the amount. ${ }^{98}$ The test as stated by the Supreme Court in Maple Leaf Mills Ltd.,99 is that:

... for an amount to become receivable in any taxation year, two conditions must coexist: (1) a right to receive compensation; (2) a binding agreement between the parties or a judgment fixing the amount. ${ }^{100}$

Where the property that is sold is a property acquired or deemed to have been acquired by the taxpayer before 1972, under circumstances that would not have entitled the taxpayer to treat the cost thereof as a drilling and exploration expense but which property would be treated as a Canadian resource property under the amended Act had it been acquired after 1972,101 only a relevant percentage of the proceeds of

97a.I.T.A. subsection $59(1.1)$.

98. M.N.R. v. John Colford Contracting Company Limited [1960] C.T.C. 178, 60 D.T.C. 1131 (Exch. Ct.) affd [1962] C.T.C. 546; 62 D.T.C. 1338 (S.C.C.). See also M.N.R. v. Benaby Realties Limited [1967] C.T.C. 418; 67 D.T.C. 5275 (S.C.C.), and Vaughan Construction Company Limited v. M.N.R. [1970] C.T.C. 350; 70 D.T.C. 6268 (S.C.C.).

99. Maple Leaf Mills Limited v. M.N.R., [1976] C.T.C. 76 D.T.C. 6182 (S.C.C.).

100. Id. at 330 and 6186 .

101. Specifically the property in question is a property that would be a Canadian resource property had it been acquired after 1971 but is not a property referred to in section $59(1.1)(b)$ of the Act. The property referred to 
disposition will be accounted for as a deduction to the taxpayer's cumulative Canadian development expense.102 The "relevant percentage" 103 is $60 \%$ plus the percentage (not exceeding $40 \%$ ) obtained when $5 \%$ is multiplied by the number of full calendar years in the period commencing at the end of 1972 and ending with the end of the calendar year in which the disposition is made. ${ }^{104}$

The taxpayer will only be required to recognize income as a result of the disposition of a Canadian resource property if the cumulative Canadian development expense is in a negative balance at the end of the year. In that event the amount of such negative balance will be taxable as income under paragraph 59(3.2)(c) of the Act.

Where the proceeds of disposition that are receivable in the year are not due until a subsequent year, the taxpayer may claim a deduction under subsection 64(1.1) of the Act. The deduction is limited in the year of disposition to the lesser of:

(a) the negative balance of the cumulative Canadian development expense included in income, and

(b) the portion of the proceeds of sale that is not due until after the end of the taxation year. ${ }^{105}$

In the following years the deduction claimed in the year of sale must be included in income.106 The taxpayer is, however, entitled to a deduction in each year equal to the lesser of the amount deducted in the previous year and the portion of the proceeds of disposition not due in the year. ${ }^{107}$ This process is repeated annually until the deduction claimed in a previous year first exceeds the then unpaid portion at the end of the year at which time the excess must be recognized as income.

Although the deduction for unpaid amounts is calculated on a property-by-property basis it would appear that where the vendor has disposed of more than one Canadian resource property in a particular taxation year he will be required to aggregate the amounts that remain unpaid under the instalment sale contracts for each property in determining the amount of deduction allowed for the year.

No deduction is permitted, however, if in the year in which it is being claimed, or in the immediately following year, the taxpayer ceases to be a resident of Canada or if a non-resident ceases to carry on business in Canada or becomes exempt from tax in Canada by virtue of a specific provision under Part I of the Act.108 Thus, persons who are non-resident in Canada will be unable to sell Canadian resource properties on an instalment sale basis and claim a reserve in respect thereof unless they continue to carry on business in Canada. If, as a result of the sale of the

in paragraph $59(1.1)($ b) is a property acquired by a principal business corporation or an oil and gas partmership, that is a right, licence or privilege to explore for, drill for, or take in Canada petroleum, natural gas or related hydrocarbons (except coal) that was acquired under an agreement or other contract or arrangement under which there was not also acquired any other right to over or in respect of the land in respect of which such right, licence or privilege was so acquired except the right . . . (8ee $83 A(5 a)(a)$ and (b). For a discussion of subsection $83 \mathrm{~A}(5 \mathrm{a})$ of the old Act wherein these rights are described, see New Continental Oil Companies of Canada Led. v. M.N.R., supra, n. 43.

102. I.T.A. paragraph $59(3.1)(a)$.

103. I.T.A. subsection $59(4)$.

104. Where a property subject to the "relevant percentage" rules is sold in a non-arm's-length transaction the purchaser will treat as his cost the vendor's "relevant percentage". If and when that property is sold by him the sale will also be subject to the relevant percentage rules. I.T.A. paragraph $59(3.1)(b)$.

105. I.T.A. paragraph $64(1.1)(a)$.

106. I.T.A. subsection $59(2.1)$.

107. I.T.A. paragraph $64(1.1)(b)$.

108. I.T.A. subsection 64(2). 
resource properties, the non-resident ceases to carry on business in Canada he will be required to recognize the full proceeds of disposition in the year of sale notwithstanding that it may not be payable for some time.

Somewhat surprisingly the unpaid portion of the proceeds of disposition of a Canadian resource property is itself treated as a Canadian resource property. ${ }^{109}$ Consequently, where such a receivable is assigned by the vendor any consideration received therefor will be treated as proceeds of disposition of a Canadian resource property. As well, it is not clear whether the assignor would be entitled to a deduction in the year of the assignment to offset the amount that must be included in income in respect to the deduction claimed in the previous year. The potential for double taxation under these circumstances is significant. However, the purchaser of such a receivable would appear to be entitled to treat his cost as a Canadian development expense and would not be required to include any amounts received under the contract as income. ${ }^{110}$

\section{Other Dispositions}

Virtually every transaction involving petroleum and natural gas rights will be treated as a disposition of property. It does not follow, however, that these transactions must be recognized as giving rise to any proceeds of disposition.

The basic petroleum and natural gas lease will be treated as a disposition of the working interest by the lessor to the lessee. As a general rule the lessor will receive a royalty payable out of the production from the lease. This is treated as an exception from the grant and does not as a rule constitute proceeds of disposition. If, however, the lessee pays to the lessor a sum in consideration of the grant of the lease, the lessor will be required to treat the payment as proceeds of disposition of Canadian resource property.

Amounts paid by the lessee to the lessor in respect of the creation of the lease will be treated as the cost of acquisition of a resource property and a Canadian development expense within the meaning of section 66.2 of the Act. If the fee simple was owned by the lessor on December 31, 1971 the "relevant percentage rules" are applicable and only a prescribed percentage of any payments made upon the creation of the lease must be recognized as income by the lessor. If the lessor and lessee are not dealing at arm's length only the corresponding "relevant percentage" of the payment made is a Canadian development expense of the lessee. An interesting question arises as to whether on a subsequent disposition of the lease by the lessee the relevant percentage rules will be applicable. Although it is arguable that the rights created under the lease were owned by the lessor on December 31,1971 the better view is to the effect that these rights have come into existence upon the creation of the lease and therefore were not owned by the lessor on December 31, 1971. As a result, any subsequent disposition by the non-arm's length lessee will not be subject to the relevant percentage rules under section 59.

If the proceeds of disposition are based on production under the lease

109. I.T.A. subparagraph $66(15)(c)(v i)$.

110. This is the case as the amounts received by the purchaser are not income from a business or property but a return of capital. The receipts are not taxable under section 59 as the payments are not in respect of a dispostion of a Canadian resource property by him. 
they will be taxable as income from a business or property pursuant to paragraph 12(1)(g) of the Act. Paragraph 12(1)(g) states:

There shall be included in computing the income of a taxpayer for a taxation year as income from a business or property such of the following amounts as are applicable:

(g) any amount received by the taxpayer in the year that was dependent upon the use of or production from property whether or not that amount was an instalment of the sale price of the property (except that an instalment of the sale price of agricultural land is not included by virtue of this paragraph).

Although not expressly stated, paragraph $12(1)(\mathrm{g})$ would appear to override the operation of subsection 59(1.1) and related sections. Thus, if a taxpayer were to sell an oil and gas property for a sum certain the payment of which was dependent upon the production of petroleum and natural gas from the sold properties, the proceeds of sale would not be treated as proceeds of disposition of a resource property but instead would be treated as income from a business or property pursuant to section 12(1)(g) of the Act. This results in a significant difference in treatment in that the vendor is not entitled to include the amount in calculating his cumulative Canadian development expense in the year of sale or in the year in which the payments called for under the agreement for sale become payable. Consequently, any Canadian development expenses of the taxpayer will be deductible only upon a $30 \%$ declining balance basis as opposed to being fully deductible were'the payments characterized as proceeds of disposition of a Canadian resource property.

The position of delay rentals payable under a lease is, however, less clear. Prior to May 6, 1974 these items were included within the defintion of Canadian exploration and development expenses deductible pursuant to section 66 of the Act. However, no similar provision is contained in either section 66.1 or 66.2 of the Act. As the payment of a delay rental is not really the performance of a contractual obligation but rather the occurrence of an event which under the lease extends its duration for another year, it is doubtful that the payment can be regarded as a currently deductible expense in computing the annual operating profits of the taxpayer. At best it is likely that the expenses will be treated as Canadian development expenses and included within the cumulative Canadian development expense of the taxpayer in the year in which they are incurred.111

Under the current administrative practice of the Department of National Revenue a farmout is also treated as a disposition of a portion of the working interest but without recognition of any proceeds of disposition. Paragraph 11 of Interpretation Bulletin IT 125R states:

It is possible to have a disposition under a farm-out arrangement that does not give rise to income. A common form of farm-out agreement is one under which the owner of a resource property transfers a part interest in it to another person who undertakes to perform on the property farm-out services, at his own expense, in the form of exploration and development expenses. In these circumstances, to the extent that the disposition of part of the interest can be considered a payment for farm-out services, the disposition does not give rise to proceeds of disposition that are accounted for in the manner outlined in the above paragraph.

Paragraph 11 should not, however, be too broadly construed. It only applies where the farmout services are in the form of exploration and

111. See McDonald, Current Developments in Oil and Gas Income Taxation, supra, n. 50 (1976) 14 Alta. L. Rev. 383. 
development expenses. While farmout services would likely be construed to include payment of the cost of tangible equipment directly related to completion of the well, it is unlikely that it will cover any other forms of tangibles. It would not include, for example, the cost of a gas plant.

It is not clear whether the Department of National Revenue would apply paragraph 11 to an arrangement whereby the farmee earns an interest in lands of the farmor other than lands in respect of which the exploration is being undertaken. For example, it seems unlikely that the Department of National Revenue would view an arrangement whereby the farmee drilled exploratory wells on exploratory acreage of farmor in exchange for an interest in proven acreage as a farmout contemplated by paragraph 11. However, while paragraph 11 states that the work must be performed on the land in which the interest is being earned, this should be construed as covering arrangements whereby the drilling of a well earns an interest in acreage that is geologically contiguous to the spacing unit on which the earning well is being drilled.

The Department of National Revenue apparently views a farmout as covering only that case where the farmor retains an undivided working interest in the lease. If, as a result of the farmout, the nature of the interest reserved to the farmor differs from the nature of the interest originally owned by him the transaction will be viewed as an exchange of properties. Thus, where the arrangement contemplates a reservation by the farmor of a gross overriding royalty, the Department of National Revenue will regard the farmout as an exchange of resource properties, being the assignment of the working interest and the creation of the gross overriding royalty, which must be reflected in the cumulative Canadian development expense accounts of the parties. As a practical matter this theoretical difference in treatment will not usually affect the tax position of the parties as the costs of acquisition of the respective properties will offset in each party's cumulative Canadian development expense the proceeds of disposition recognized on the exchange. If the interest being farmed out includes depreciable property, an allocation must be made as between the resource properties and the depreciable property according to the relative expenses. It is possible therefore that income in the form of recaptured depreciation may be recognized by the farmor on the exchange.

While there are also some theoretical difficulties with the characterization of the transaction as applied by the Department of National Revenue where partnerships or Crown corporations are involved, these are, or will be, alleviated under proposed legislative amendments and the current administrative practice of the Department of National Revenue.

\section{SPECIAL ALLOWANCES}

The Income Tax Regulations provide for specific allowances in respect of a taxpayer's oil and gas related income. Earned depletion which became effective on May 7, 1974 effectively ties the amount of the allowance to expenditures incurred in the process of exploring for and developing oil and gas properties. Under the earned depletion concept taxpayers will be entitled to depletion only to the extent that it has been earned. For every $\$ 3.00$ of eligible expenditures incurred, a taxpayer will earn the right to $\$ 1.00$ of earned depletion. The deduction permitted will be equal to the lesser of $25 \%$ of the taxpayer's "resource profits" and his 
"earned depletion base" at the end of the year to the extent that it was not deductible by him in calculating his income for previous taxation years. The "resource allowance", which is effective generally from January 1,1976 , is more liberal and essentially permits a deduction equal to $25 \%$ of the taxpayer's "resource profits" calculated after operating expenses and capital cost allowances but before the deduction of interest expense, exploration and development expense and earned depletion. ${ }^{112}$

\section{Earned Depletion}

Section 1201 of the Regulations ${ }^{113}$ permits a deduction equal to the lesser of $25 \%$ of a taxpayer's resource profits and his earned depletion base as of the end of the year.

For the purposes of the Regulations the resource profits of a taxpayer will, with respect to his oil and gas operations, be the amount, if any, by which the aggregate of his income for the year from the production of petroleum and natural gas and related hydrocarbons from oil and gas wells in Canada operated by him, rentals or royalties based on the production from oil and gas wells in Canada and amounts included in income by virtue of a negative cumulative Canadian exploration expense or negative cumulative Canadian development expense exceeds the aggregate of the taxpayer's losses for the year from such sources. For these purposes the income or loss will be computed in accordance with the Act on the assumption that the taxpayer had during the year no income or losses except from those sources and was allowed no deductions in computing his income for the year other than amounts deductible under section 66 of the Act, 66.1 of the Act, 66.2 of the Act and such other deductions as may reasonably be regarded as applicable to the sources of income described above. ${ }^{114}$

The earned depletion base of such a taxpayer will generally include one-third of the taxpayer's expenses incurred by him after November 7, 1969 in exploration and drilling in Canada exclusive of costs incurred in respect of the acquisition of Canadian resource properties.

The taxpayer's earned depletion base must be deducted to the extent permitted under the Act and failing such deduction will not be deductible in a subsequent taxation year. Furthermore, if the taxpayer is a corporation that has ceased to carry on an active business, and between the time when it ceased to carry on an active business and when it commenced to carry on an active business again, control has been acquired by a person, or other persons with whom that person did not deal at arm's length who did not control the corporation at the time when it so ceased to carry on active business, the earned depletion base of the corporation will be reduced by an amount equal to its earned depletion base at the time control was so acquired.

Where a corporation has acquired all, or substantially all, of the assets of another corporation under circumstances where the predecessor-successor rules are operative, the earned depletion base of

112. Earned depletion deductible by virtue of the predecessor/successor rule will, however, reduce the base for the resource allowance.

113. Passed pursuant to I.T.A. section 65

114. The income or loss from the production of petroleum, natural gas or related hydrocarbons is deemed not to include the income or loss derived from transporting, transmitting or processing petroleum, natural gas or related hydrocarbons. See Texaco Exploration Company v. The «ueen [1975] C.T.C. 404: 75 D.T.C. 5288 (F.C.T.D.) 
the predecessor corporation will be deductible by the successor (and second successor) corporation. The deduction is however limited to the extent of $25 \%$ of the qualifying income (as defined for the purposes of the predecessor-successor rules under the Act) less the expenses of the predecessor corporation that are under those rules deductible by the successor corporation against such income. ${ }^{115}$

If the taxpayer is a member of a partnership carrying on oil or gas operations in Canada, the earned depletion allowance available with respect to such operations is deductible by him personally and not at the partnership level. Thus, a partner's earned depletion base will generally include his share of expenses incurred by the partnership that would have been included in his earned depletion base had they been incurred by him personally. In addition, subsection 1206(3) of the Regulations provides that the resource profits of the partnership for the fiscal period will, to the extent that of taxpayer's share thereof, be included in computing his resource profits for his taxation year in which the fiscal period ended. Although the point is unclear the Regulations seem to require that the partner treat his share of partnership resource profits as being subject to the deduction of other expenses incurred by him as partner for the purpose of determining his resource profits for the year.

\section{Resource Allowance}

\section{Section 1211 of the Income Tax Regulations provides:}

For the purposes of paragraph $20(1)(v .1)$ of the Act, there may be deducted in computing the income of a taxpayer for a taxation year an amount equal to $25 \%$ of his resource profits for the year within the meaning of subsection 1204(1) if that subsection were read without reference to paragraph (a) or subparagraph (b)(iv), computed as if no amounts were deducted in computing those resource profits under paragraph 1204(1)(d) or (e) or paragraph $20(1)(c)$, (d) or (v.1) of the Act.

Thus, resource profits will be calculated without the inclusion therein of amounts otherwise included in computing the taxpayer's income for the year under paragraphs $59(3.2)(\mathrm{b})$ and (c) of the Act by virtue of the taxpayer's Canadian exploration expense and Canadian development expense being in a negative balance at the end of the taxation year. However, no deduction need be claimed in respect of Canadian drilling and exploration expenses deductible under the Income Tax Application Rules, Canadian exploration and development expenses deductible under section 66 of the Act, or the taxpayer's cumulative Canadian exploration expense or cumulative Canadian development expense deductible under sections 66.1 or 66.2 of the Act. As well financing costs deductible pursuant to paragraphs 20(1)(c) or (d) of the Act need not be deducted. However, all other deductions that may reasonably be regarded as related sources of income included in calculating resource profits shall be deducted in computing the resource profits for the purposes of the resource allowance.

Unlike the earned depletion allowance the resource allowance must be claimed at the partnership level.

115. Predecessor/successor depletion will be deductible to the extent of qualifying income; prior to the deduction of the earned depletion of the successor corporation itself. It is noted however that the deduction will reduce the resource profits for purposes of the resource allowance. 